\title{
ORGANIZATIONAL IMPROVISATION: \\ A CONSOLIDATING REVIEW AND FRAMEWORK
}

\author{
Allègre L. HADIDA* \\ University of Cambridge \\ Judge Business School and Magdalene College \\ Trumpington Street, Cambridge CB2 1AG \\ United Kingdom \\ Tel.: + 44 (0) 1223339612 \\ E-mail: a.hadida@jbs.cam.ac.uk
}

William TARVAINEN

E-mail: william.tarvainen@gmail.com

June 2014

Forthcoming in International Journal of Management Reviews

We gratefully acknowledge the very helpful comments of Tim Edwards, Katie Jones, Joe Lampel, Allan Macpherson, Jed Rose, Mark Thompson, Paul Tracey and two anonymous reviewers on earlier versions of this article. All errors and omissions remain ours. 


\title{
Organizational Improvisation: A Consolidating Review and Framework
}

\begin{abstract}
Organizational improvisation is increasingly recognized as a relevant area of management research. However, the cumulativeness of research on improvisation in organizations remains low. This article organizes existing contributions on organizational improvisation within a new consolidating framework combining degrees (minor, bounded, and structural) and levels (individual, interpersonal, and organizational) of improvisation. The proposed degree/level framework allows for reviewing the existing literature on organizational improvisation in the management disciplines of strategy, organizational behavior, organizational theory, innovation and marketing in a systematic manner. It also exposes potential areas for future research across management disciplines, research areas, organizational settings and industries, and beyond existing metaphors, most notably of jazz and improvisational theatre.
\end{abstract}

\section{Keywords}

Organizational Improvisation, Metaphor, Jazz, Improvisational Theatre, Creativity 


\section{Organizational Improvisation: A Consolidating Review and Framework}

\section{Introduction}

Accelerating globalization, trade liberalization and the increased interconnectedness permitted by advances in information systems and the Internet render long-term plans obsolete at a moment's notice, and force organizations to nimbly and creatively navigate constantly evolving landscapes (D’Aveni 1994; Hamel and Breen 2007; Schreyögg and Sydow 2010). To illustrate their ability and willingness to improvise and adapt to changing circumstances, some multinationals compare themselves to "a jazz band, not a symphony orchestra" (Steinbock 2010: 107). Chief Executive and former professional comedian Dick Costolo also reports that he regularly applies lessons learned from improvisational theatre to running Twitter (Bilton 2012).

As emergent strategies decreasingly conform to deliberate strategizing (Mintzberg and Waters 1985), organizational improvisation (OI) combines with heuristics ${ }^{1}$ to help managers understand and analyze organizational decisions and actions that display the following characteristics. They are complex and dynamic, cannot be understood a priori or managed using existing routines, and demand flexible and extemporaneous action (Ciborra 1999; Kamoche and Cunha 2001; Kirsch 1996). OI may thus enable companies to subdue more of the emergent part of their actions and environmental fortuities to their own will (Cunha et al. 1999), in particular in environments characterized by high velocity, heterogeneity in experiences, plentiful opportunities and high unpredictability (Bingham and Eisenhardt 2011, 2014).

Yet, fifteen years after Cunha's et al. (1999) first review, the cumulativeness of OI research remains low. None of the existing taxonomies takes full account of the different types of improvisation, and most are specific to a single metaphor (in particular, jazz or less frequently, improvisational theatre). The absence of a consolidating framework of OI may be justified under the assumption that improvisation may be inherently uncontained, and that discussions of improvisation may be inherently distorted by the need to force its manifestations into a model. Even so, this absence poses a threat to the future congruence of the field.

The framework of OI introduced in this article addresses these concerns. It illustrates when and under which circumstances OI is inherently uncontained, and when it is not. It also allows for the continual testing of the boundaries of what is and is not legitimately included in discussions of $\mathrm{OI}^{2}$ More generally, it synthesizes metaphorical, empirical and anecdotal 
works to advance a typology that covers the different forms of understanding OI. The proposed framework allows for reviewing the existing literature on OI in strategy, organizational behavior, organizational theory, innovation, and marketing in a systematic manner, and exposes areas for future research across these five management disciplines and beyond specific improvisation metaphors.

The next section details our research methodology, and outlines the evolution of OI research before and after Cunha's et al. (1999) first consolidating review. Section 3 introduces the definition of OI adopted in the article, and examines the "why" (rationale) and "how" (namely, metaphorical and naturalistic studies) of OI research to date. Section 4 lays the foundations of the proposed framework of OI. It discusses six taxonomies most commonly used in the OI literature, and defines degrees (minor, bounded and structural) and levels (individual, interpersonal and organizational) of OI. The combined degree/level framework of OI is introduced in Section 5. A discussion and conclusions section summarizes our findings, highlights the contributions and limitations of the degree/level framework and suggests directions for further research.

\section{Methodology}

Although organizations and their members have always improvised to some degree, research into OI is relatively recent. The academic field of management was slow to transcend the historical principles of managerial planning (Taylor 1911) and the definition of improvisation as a dysfunction in planning (March and Simon 1958) or in organizational design (MacKenzie 1986) put forward by the formal strategizing approach (Chandler 1962). New management perspectives emerged in the 1980s to respond to an increasingly dynamic business environment. They challenged conventional wisdom by noting that the environment may change before elaborate plans can be implemented, and by advising managers to create organizations that can flexibly respond to such changing circumstances (Mintzberg 1990; Mintzberg and McHugh 1985; Mintzberg and Waters 1985). Although initially contentious (Ansoff 1991; Mintzberg 1991), these developments led management research to shift its focus towards addressing change and OI (e.g., Jackson and Philip 2010).

This article offers a systematic and comprehensive account of research published in English and investigating OI in strategy, organizational behavior, organizational theory, innovation, and marketing up to June 2014. These five disciplines of management were chosen on the basis of the importance of OI research carried out within their boundaries. We undertook data collection in three complementary steps. 
We first carried out systematic manual and electronic searches for all articles published on OI in the following journals. For strategy, organizational theory and organizational behavior: Academy of Management Journal, Academy of Management Review, Administrative Science Quarterly, Organization Science, Strategic Management Journal, Journal of Management Studies, Journal of Management, Organization Studies and Organization; for innovation: $R \& D$ Management and Research Policy; and for marketing: Journal of Marketing, Journal of Marketing Research and Marketing Science. These journals were selected on the basis of their relevance to academic research in the five disciplines under study and of their high impact factors. We undertook this first step to make sure that we did not inadvertently overlook OI articles published in top journals.

We then expanded and complemented this first collection with systematic reviews of OI articles in all other publications listed on EBSCO, JSTOR and ScienceDirect. The keywords "improvisation", "organizational learning”, "spontaneous action", "spontaneous process", "chaos", "order", "structured", "planning", "jazz" and "theatre" were used to refine the electronic searches. This second step led to the identification of articles dealing with OI in a number of other journals, including (yet not limited to): British Journal of Management, International Journal of Management, Sloan Management Review, and Journal of Organizational Change Management. Third, we visited three libraries to search for additional publications, in particular books and monographs: the London Business School Library (London, UK), the University of Cambridge Central Library (Cambridge, UK), and the Sibelius Academy Library (Helsinki, Finland).

As Figure 1 attests, studies of OI published before 1990 were few and far between. Following a very successful symposium at the 1995 Academy of Management Conference in Vancouver (Frost 1998, Meyer et al. 1998), their number peaked in 1998 with the publication of a special issue of Organization Science. A review article in the International Journal of Management Reviews followed in 1999 (Cunha et al. 1999). Our final sample, give or take involuntary oversights, constitutes the whole population of OI research in the selected five disciplines of management up to June 2014. It consists of 197 studies: 149 articles and working papers, 13 book and conference proceedings chapters, and 35 books and monographs. The overwhelming importance of peer-reviewed empirical articles within this population primarily reflects their precedence in disseminating knowledge in the five selected disciplines.

\section{Insert Figure 1 about here}


Research published before Cunha et al. (1999) mostly developed along two streams. The first proposes arts-based metaphors, in particular jazz, to illustrate and shed light on improvisation in organizations (e.g., Hatch 1998). This first stream relies heavily on secondary data from musicology monographs (Berliner 1994; Kernfeld 1995; Schuller 1968) and builds on specific authors' experiences of jazz as audiences or - on rare occasions musicians (Peplowski 1998; Barrett and Peplowski 1998). The second stream of research uses empirical, naturalistic-based illustrations and anecdotal evidence to define improvisation and its causes and effects within organizations (e.g., Crossan and Sorrenti 1997). Both research streams have succeeded in creating interest in OI as a research topic and organizational phenomenon (e.g., Weick 1998).

Noticeable shifts in focus of OI research after 1999 call for a new review. New metaphors of OI have emerged (e.g., Kamoche et al. 2000, 2003), and the improvisational theatre metaphor has gained in strength (e.g., Moss Kanter 2002; Vitug and Kleiner 2007). Post-1999, a larger number of contributions set out to investigate empirical implications of OI, particularly in new product development (e.g., Akgun and Lynn 2002; Samra, Lynn and Reilly 2008), in new ventures (Hmieleski and Corbett 2008; Evers and O'Gorman 2011), and under conditions of change and turbulence (Charles and Dawson 2011; Leybourne 2006). The methodology adopted in OI research has also shifted in recent years from a focus on detached theorizing in metaphorical works to conceptually rigorous in-depth case studies and interviews carried out in organizations (e.g., Bigley and Roberts 2001; Plowman et al. 2007; Sonenshein forthcoming) or about specific events (e.g., Mendonca and Wallace 2004; Brady 2011) during which improvisation took place.

\section{Taking Stock: Definition, Rationale for and Existing Studies of OI}

\section{Organizational Improvisation: A Definition}

As a young, interdisciplinary and occasionally uncontained concept, OI has struggled to develop a comprehensive definition. There is, however, a high level of agreement on many of its properties (Vera and Crossan 1999). The word improvise comes from the Latin providere, "make preparation for", and its derivative improvisus, "unforeseen" (Oxford Dictionaries 2014). Improvisation thus involves dealing with the unforeseen without the benefit of preparation.

Improvisation is organizational when it is done by the organization or its members. It therefore occurs at various levels, and different dynamics apply to it depending on whether 
improvisation happens within one (individual), between two or a few (interpersonal) or amongst many (organizational) individual actors. Table 1 provides an overview of central OI research, which it lists by primary level. As Table 1 illustrates, OI research has mainly focused so far on the individual and organizational levels. There also seems to be no major trend in how contributions differ in their description of improvisation. Since improvisation is a fairly commonly used concept in everyday discourse and given the challenges associated with trying to contain it, some research even eschews all explicit definitions of OI. Taking the term for granted, however, may lead to confusion and misunderstandings.

\section{Insert Table 1 about here}

The overarching theme in the literature featured in Table 1 is spontaneous action without preparation, described mainly as convergence of composition and performance (nine papers in Table 1, including Baker et al. 2003; Crossan et al. 2005), unfolding (five papers, including Barrett 2000; McKnight and Bontis 2002), and emergence (four papers, including Hutchins 1991; Lockford and Pelias 2004). Some authors also define spontaneous action without preparation as extemporaneousness (e.g., Moorman and Miner 1995; Schuller 1968), immediacy (e.g., Weick 1993b, 2001; Lockford and Pelias 2004); quickness (e.g., Meyer 1998; Holbrook 2007); and real-time formulation and implementation (e.g., Perry 1991; Pasmore 1998). Others see individual reflection in or on action as a key element of responsive action (Schön 1987; Yanow and Tsoukas 2009). Closely related recurring concepts are spontaneity (twelve papers in Table 1), bricolage (six), intuition (four), and "adhockery" (two).

In what follows, we define OI as the conception of unhindered action as it unfolds, by an organization or its members, often (yet not exclusively) in response to an unexpected interruption or change of activity. This definition foregoes additional qualifiers, since its austerity already obliges organizations and organizational actor(s) to act extemporaneously, spontaneously, intuitively and $a d$ hoc in an emergent manner. The convergence of planning and action is also not used in this definition, since it seems to imply that any rapid decisionmaking, due to a degree of convergence, is improvisational. Yet, improvisation is not deciding just before acting but whilst acting. OI is generally assumed to take place first and foremost in organizations that tolerate failure (Cunha et al. 2009; Sonenshein forthcoming), have a working environment that supports improvised work (Leybourne 2010b), and have minimal resistance to change (Leybourne 2006). In some instances, improvisation may also 
act as a political statement and serve a political agenda within the organization (Janos and Rich 1994).

\section{Rationale for Organizational Improvisation}

Weick notes that: "even if organizations are capable of improvising, it is not clear they need to do it" (2001: 301). Unforeseen circumstances are not a necessary condition for improvisation: jazz bands, for instance, or newly formed start-up teams fully expect improvisation. Even so, OI is often triggered by some unexpected event that requires immediate action and cannot be addressed using pre-approved, "safe" routines and solutions (Hatch 1997; Moorman and Miner 1998b; Weick 1993a). Dealing with the unforeseen may involve removing barriers to instinctual ideas, or building new ideas out of nothing. The unforeseen may come either from outside or within the organization.

From outside the organization, the external environment may become so complex as to render planning unfeasible (Cunha et al. 1999) or counterproductive (Mintzberg 1994). The organization may also face market and technological turbulence (Akgun et al. 2007; Nunez and Lynn 2012; Pavlou and El Sawy 2010), or an unpredictable environmental shock (Chelariu et al. 2002; Crossan et al. 1996) or crisis (ten Brinke et al. 2010; Mendonca and Wallace 2004; Webb and Chevreau 2006). Such disruptions may compel the organization to improvise (Crossan and Sorrenti 2002) and to proactively train itself to improvise crisis procedures - for instance, in the context of mental simulations of initial responses to aircraft accidents (Barreto and Ribeiro 2012) or in response to the situated practices and problems of users implementing large-scale Enterprise Resource Planning (ERP) change (Charles and Dawson 2011). OI scholars generally agree that external triggers for improvisation proliferate as markets become more dynamic.

From within the organization, the impulse to improvise may come about when the enactment of a new vision requires emergent changes (Mintzberg and McHugh 1985) that may be addressed by improvisation (Crossan et al. 1996; Perry 1991). As the organization deliberately develops safer contexts for improvisational actions, skunk-works teams may also work on specific projects in unconventional ways with an aim to developing them fast and with minimal managerial interference (Janos and Rich 1994; Moorman and Miner 1998a). By improvising, an organization seeks to gain longer-term benefits beyond the situation at hand. It may also break free from flawed mental models of itself and its environment susceptible of preventing it from predicting otherwise foreseeable changes (Cunha et al. 1999; Senge 1990). Improvisation is commonly seen to promote greater organizational flexibility (Cunha et al. 
1999). Even so, Barrett's (1998) discussion of "provocative competence" mostly concerns top-down provocation, and Berniker states that: "The task of the managers' jazz combo is to make music. The role of employees is to dance" (1998: 583).

Improvisation brings high autonomy in the context of clear rules (Cunha et al. 2003). It may help the organization to learn to improvise better (Crossan et al. 1996; Chelariu et al. 2002), to innovate (Vera and Crossan 2005), to explore new solutions (March 1991), or to perform certain activities better through routinizing successful improvisations (Miner et al. 1997; Ferriani et al. 2011). Team improvisation also positively impacts the effectiveness of new product development processes (Akgun and Lynn 2002). Coupled with unlearning and in conditions of environmental turbulence, it facilitates team flexibility, learning and new knowledge development (Chelariu et al. 2002). Ultimately, team improvisation influences new product success (Akgun et al. 2007). Among employees, OI may lead to higher motivation (Eisenberg 1990), to feelings of success (Eisenberg 1990) or to stronger teams (Powers 1981). In increasingly inter-connected organizational ecosystems, acting in interfirm networks that do not have a single leader also often involves OI (Pavlovich 2003).

OI however has a dark side, and may not be significantly associated with satisfactory project outcomes (Leybourne and Sadler-Smith 2006). Thus, entrepreneurs who are avid improvisers and confident in their ability to succeed may develop new ventures with record sales growth, but they also seem to be the least satisfied with their work (Hmieleski and Corbett 2008). This result may be due to a tendency to spread themselves too thinly (Baker and Nelson 2005), and points to the risk of stress and psychological burnout associated with excessive improvisation (Hatch 1999). By going against the idea that improvisers find themselves in the enhanced mental state of "flow" (Csikszentmihalyi 1990) or "groove" (Barrett 1998, 2000) when improvising, this result may also reveal limitations of the theatre and jazz metaphors of OI (Hmieleski and Corbett 2008).

The effects of improvisation on financial performance may be delayed in time (Bergh and Lim 2008), and improvisation may even have negative organizational consequences (Aram and Walochick 1996). Organizations may over-eagerly generalize successfully improvised solutions to wrong contexts (Kamoche and Cunha 2001), and neglect planning and preparation by over-legitimizing OI (Eisenberg 1990). Excessive improvisation and improvisation without clear rules and boundaries may lead to lack of focus and unwanted variation in the delivery of products or services (Cunha et al. 2009: 666; Hatch 1999). Tackling every challenge with an ad hoc improvisational task force may also hinder the development of experience-based teams (Kamoche and Cunha 2001; Weick 1998). 
Ultimately, organizations consistently struggle to achieve a balance between countervailing forces of organizational efficiency (control) and adaptability (improvisation) (Ciborra 1999; Leybourne 2010a; Nunez and Lynn 2012; Schreyögg and Sydow 2010). Large-scale distributed systems specifically deal with the improvisational paradoxes of learning (learned improvisation and reflective spontaneity), organizing (planned agility and structured chaos), and belonging (collective individuality and anxious confidence) through the "enacted emergence" of collective agility (Zheng et al. 2011). On balance, researchers tend to emphasize positive over negative outcomes (Magni et al. 2008; Vera and Crossan 2005), and OI may show positive effects in the right context (Vera and Crossan 2005). Yet, improvisation is inherently neither positive nor negative (Baker, Miner and Eesley 2003; Crossan et al. 2005; Magni et al. 2009; Miner et al. 2001).

\section{Metaphors and Empirical Studies of Organizational Improvisation}

Since improvisation in organizations involves a number of human actors dependent on complex local circumstances, individual instances of OI are hard to model. Improvisation is generally more openly discussed and documented in the arts (including music, theatre and dance) than in business, and using metaphors derived from these sectors allows researchers to draw meaning from alternative sources. A metaphor is a "comparative figure of speech [...] through which humans create meaning by using one element of experience to understand another" (Morgan 1980, 1998: 4). As an "invitation to see the world" (Barrett and Cooperrider 1990: 222), a metaphor presents an alternative social reality (Tsoukas 1993), and connects the lay and scientific discourses (Tsoukas 1991). It also offers "an epistemologically valid approach to making sense of organizations" (McCourt 1997: 511).

Metaphors used to explain improvisation include conversation (e.g., Berliner 1994; Hatch 1998; Ramos 1978; Weick 1998), problem solving (Bernstein 2000; Ramalho and Ganascia 1994), games (Hudak and Berger 1995), stories (Tanenbaum and Tanenbaum 2008), and role theory, Indian music and music therapy (Kamoche et al. 2000; 2003). Improvisational theatre is the second-most common metaphor in OI (Crossan 1997, 1998; Crossan et al. 1996; Gagnon et al. 2012; Gibb 2004; Koppett 2002; McKnight and Bontis 2002; Meyer 2005; Singh and Sonnenburg 2012; Vera and Crossan 2004, 2005; Vitug and Kleiner 2007; Weick 1993a). As theatrical interaction happens primarily with words, its lower level of abstraction generally makes theatrical improvisation more intelligible to people than musical improvisation. 
Even so, OI has been associated with jazz from the outset (Bastien and Hostager 1988). To this day, jazz improvisation has spawned more OI literature than all other metaphors combined, and has become the primary hermeneutic and sense-making metaphor for explaining improvisation in organizations. Correspondingly, most taxonomies of OI use specific jazz terms to illustrate particular types of improvisation. The following reasons may explain the prevalence of the jazz improvisation metaphor.

First, researchers resorting to it may assume that it will resonate more with readers and organizations than other metaphors. Whereas jazz and improvisation are intrinsically linked in people's minds, improvisation is less readily associated with symphony orchestras or baroque music (for instance) - even though it is also practiced within such musical formations and genres. Second, jazz represents improvisation at its most intricate (Kamoche et al. 2003), and offers 97 years of documented development since the first recording in 1917 of Livery Stable Blues by the Original Dixieland Jazz Band. Third, jazz improvisation provides a wealth of parallels to OI. It starts from a certain structure that frames improvisation but does not cage it: "Although "breaking the rules" is important, musicians are aware of rules for how to innovate, rules about breaking the rules" (Sawyer 1992: 259; Crossan 1998). Moreover, just as musicians juggle between exploiting the past and exploring the future (March 1991), organizations must collectively respond to change in real time (Barrett 1998, 2012; Crossan and Sorrenti 1997; Meyer 2005; Sawyer 1992). Similarities also exist in roles and responsibilities: to improvise together, says jazz pianist Dave Brubeck, "somebody has to mind the store, to give the improviser more freedom to get out on his own" (Kao 1996b: 25). In jazz bands as in organizations, improvisation has intrinsic value when musicians or employees choose to improvise, or instrumental value when musicians or employees are made to do so, either in response to unforeseen internal or external circumstances or in exchange for incentives.

The mainstream business literature often draws parallels from jazz to organizational creativity and flexibility (Kao 1996a). Jazz can also contribute to other fields of management (Crossan et al. 2005), including: change management (Barrett and Hatch 2003; Mantere et al. 2007; Orlikowski 1996); learning and knowledge capture (Crossan and Sorrenti 2002; King and Ranft 2001; Miner et al. 2001; Vendelø 2009); new product development (Eisenhardt and Tabrizi 1995; Kamoche and Cunha 2001; Moorman and Miner 1998a; Sutton and Hargadon 1996); organizational adaptation and renewal (Brown and Eisenhardt 1997; Crossan et al. 1996); strategic decision making (Eisenhardt et al. 1997; Holbrook 2007); technology use and related change (Orlikowski and Hofman 1997); outsourcing (Silva 2002); 
negotiation (Balachandra et al. 2005; Wheeler and Morris 2002); social intrapreneurism (Grayson et al. 2014) and management education (Meyer and Shambu 2010). Our understanding of OI resulting from the jazz metaphor can also enrich and inform parallel and tangential streams of research (e.g. Bathurst and Williams 2013).

The analogy between jazz and management, however, is not perfect. Jazz may bring fresh perspectives to management, as jazz clarinetist Ken Peplowski remarks: "There's nothing worse than someone just doing their job: just doing the minimum that's required. My job as a manager would be a lot simpler and more satisfying if more employees understood improvisation. Doing the minimum is impossible in a jazz group" (Peplowski 1998: 561). Yet, the jazz metaphor has its limits: "[Jazz] is artsy, performed disproportionately by people of color, still has an undercurrent of booze and drugs surrounding it, and frankly doesn't sell that well to a broad base of customers. In short, it's the antithesis of much of what we think about when we think about business" (Mirvis 1998: 591). Although metaphorical OI research still largely outnumbers empirical OI research, some scholars consequently point out that improvisation is "more than a metaphor" (Crossan 1998: 593). They advocate going beyond critiques of the metaphor and using "jazz as a means to larger insights into collective action" (Hatch and Weick 1998: 604). They also recommend experiencing improvisation "in the context of a group that makes improvisation their profession" (Crossan and Sorrenti 2002: 45), and transcending the metaphorical level to explore what actually happens in jazz improvisation (Dennis and Macaulay 2007; Sawyer 1992).

Efforts to shift the analysis to naturalistic managerial settings (Magni et al. 2009) are manifest in empirical studies of OI. The latter deal with general (e.g., Brown and Eisenhardt 1997; Miner et al. 2001; Moorman and Miner 1998a; Orlikowski 1996) or specific activities in organizations (e.g., service performance and recovery: Chang 2006; John et al. 2006; Cunha et al. 2009), and with specific shocks that necessitate improvisation. For example, the Mann Gulch wildfire (Weick 1993b), hurricane Camille (Mendonca and Wallace 2004), the failure of a ship's navigational system (Hutchins 1991), the battle of Stalingrad (Brady 2011) or the Apollo 13 (Rerup 2001) and Columbia (Starbuck and Farjoun 2005) space shuttle crises.

Notable instances of non-crisis OI include 3M's discovery of the Post-it note (Peters and Waterman 1982), Honda's motorcycle strategy in the USA (Pascale 1984; Crossan et al. 1996), Brazilian conglomerate SEMCO's day-to-day management (Crossan et al. 1996) and the improvisation-minded "adhocracy" of the National Film Board of Canada (Mintzberg and McHugh 1985). More recent cases encompass creative resourcing (that is, acting on objects 
to creatively solve problems) in "BoutiqueCo" (Sonenshein forthcoming) and the emergent radical revitalization of "Mission Church" 3 as an inclusive outreach day center and diverse congregation (Plowman et al. 2007). Non-crisis OI also manifests itself in new venture internationalization (Evers and O'Gorman 2011; Prashantham and Floyd 2012), and festival management (Larson 2011). Empirical studies of OI usually start with a known instance of improvisation and trace its links to other organizational actions ex post (Miner et al. 2001). By linking improvised decisions to prior organizational actions, such studies also reinforce the idea that improvisation involves tapping into instinctual ideas that improvisers already know subconsciously.

\section{Moving Forward: Laying the Foundations of the Degree/Level Framework}

This section sets the foundations of a new typological framework of OI that is both generalizable and applicable across OI metaphors and naturalistic managerial settings. The proposed degree/level framework aims to overcome the field's incongruence and ensuing low cumulativeness (Cunha et al. 1999) by distinguishing between various types of OI. Currently, papers with this aim tend to distinguish either between different degrees (e.g., Kamoche et al. 2003; Moorman and Miner 1998a, 1998b; Zack 2000) or between different levels of improvisation (e.g., Crossan et al. 2005; Lewin 1998; Vera and Crossan 2004, 2005). The absence of a common typology may be seen as liberating under the assumption that $\mathrm{OI}$ is inherently uncontained, and consequently inherently uncontainable. It is a setback however to expanding, comparing and mapping existing findings.

The degree/level framework advances a typology that covers the different forms of understanding improvisation as a process that takes place in organizations. The proposed three-by-three matrix presents two core questions with simple alternative answers. First, at what level does improvisation happen: within an individual actor (individual), between two co-workers or a few in a (small) team (interpersonal), or within the entire organization (organizational)? Second, to what degree does improvisation happen: does it relate to performing an existing task in a different manner (small degree -minor), improvising a different task toward the same outcome (medium degree - bounded), or improvising a different task toward a new outcome (large degree - structural)? The following sub-sections review the most commonly used taxonomies, degrees and levels of OI. 


\section{Common Taxonomies of Organizational Improvisation}

Four nominal taxonomies (three dichotomous distinctions and one four-way classification) appear repeatedly in the improvisation literature. The three dichotomous distinctions are as follows. First, product improvisation affects the outcome of what is done, whereas process improvisation changes the way something is done (Miner et al. 1997). Second, behavioral improvisation refers to changing organizational actions, whereas cognitive improvisation gives new meaning to external stimuli (Miner et al. 1997). Third, idiomatic improvisation happens within an existing vernacular such as jazz music, whereas non-idiomatic improvisation is completely free (Bailey 1992). The first two distinctions are essentially organization-centric, and the third stems from musicology. All of them provide interesting complements to the dimensions of our proposed framework.

The four-way classification was also developed in musicology, in the context of jazz improvisation (Kernfeld 1995): paraphrase improvisation builds on existing themes; formulaic improvisation on musical formulas; motivic improvisation on musical motifs; and modal improvisation on scales. Due to their strong association with musical performance, none of these four categories is particularly well suited to feature in a framework aimed at transcending metaphors. Nor do they allow for an ordinal ranking.

Two main ordinal categorizations appear in the literature on improvisation. Again, the more common of the two stems from musicology. It is a four-part continuum of interpretation to embellishment, variation and finally "true" improvisation (Berliner 1994: 66-71). This typology presents two difficulties. First, it sets an unnecessarily low ceiling for improvisation, as improvisation that involves "reworking pre-composed material" (Berliner 1994: 241) must exist within song structures (Kamoche et al. 2003; Zack 2000) and thus cannot be structural. Second, it limits the definition of improvisation: since interpretation, embellishment and variation are mutually exclusive from improvisation, minor improvisation becomes an oxymoron. Berliner's (1994) improvisation is thus restricted to one form only: bounded improvisation.

The second main ordinal categorization distinguishes between four genres: classical with minimal to no improvisation; traditional jazz/swing with improvisation within strong structures; bebop with minimal structural modification; and post-bop with emerging structures (Zack 2000). Although this typology acknowledges the full range of improvisation from minor ("classical") to structural ("post-bop"), it is inextricably tied to music, and as such precludes generalization to other metaphors or organizational settings. 
All six classifications have contributed to improving our understanding of OI. None of them is comprehensive, however, and several are specific to music. The degree and level axes detailed in the next two sub-sections account for the main existing typologies of OI (Berliner 1994; Zack 2000) and contribute to the congruence, cumulativeness and transparency of the OI field.

\section{Degrees of Improvisation: Minor, Bounded and Structural}

Improvisation happens to different degrees, and is not a dichotomous on/off activity. These degrees can be placed on a continuum ranging from tweaking minor details to dramatically changing large structures (Schloss and Jaffe 1993), and from almost completely planned to almost completely extemporaneous (Moorman and Miner 1998b). Our proposed framework lowers the threshold and raises the ceiling of Berliner's (1994) classification to reflect the breadth of OI degrees. Degrees of improvisation range from modest improvisation within an existing process or product (minor improvisation) to improvising new processes or products within established structures (bounded improvisation), and to improvising new structures (structural improvisation).

Minor improvisation reflects modest adjustments to pre-existing processes (Moorman and Miner 1998b) - for instance, by applying an existing solution in a new way rather than coming up with a new solution. It is variously termed interpretation, embellishment or ornamentation (Berliner 1994; Hatch 1997; Preston 1991; Weick 1996). Although such processual flexibility is not unique to OI, any comprehensive typology of OI must include this lower end. Innovative embellishment of work routines happens regularly in organizations, whether encouraged or not (Brown and Duguid 1991; Meyer and Shambu 2010). Such flexibility and allowance for constant adjustments in business processes is consequently widely acknowledged across management disciplines - for instance, as flexible manufacturing in operations research (e.g., De Meyer et al. 1989; Jaikumar 1986) or as rhythmic performance in project management (Leybourne 2010a). Similarly, jazz musicians vary in timbre (that is, sound quality) even in monotonous routine performances (Berliner 1994). Jazz musicians improvising in demanding tempi or actors partaking in fast-paced improvisation league tournaments are also likely to fall back on mastered "licks" (that is, prerehearsed solutions that work well enough when the improviser has no time to explore more creative options: Berliner 1994; Weick 1998) or "simple rules heuristics" (Bingham and Eisenhardt 2011, 2014). They return to the building blocks when in doubt, in order to refocus and get the audience back on their side. 
Alternatively, minor improvisation may also reveal the existence of upper limits to improvisation in complex high-velocity environments and organizations (Cunha et al. 2003; Eisenhardt 1989). The latter call for lower degrees of improvisation defined as trying to achieve an objective in a new, creative way (e.g., Vera and Crossan 2005), and higher degrees of improvisation defined as converging composition and execution (e.g., Moorman and Miner 1998b). This discrepancy further justifies our call for a new typology of OI.

Bounded improvisation involves improvising novel processes or products within existing structures, which delineate clear boundaries and provide a template within which bounded improvisation takes place (Berliner 1994; Moorman and Miner 1998b). Scholars who do not distinguish between degrees of improvisation usually discuss it as bounded improvisation. Others refer to bounded improvisation as chorus paraphrasing (Preston 1991) or formulaic improvisation (Weick 1996).

In organizations, bounded improvisation entails incremental innovation. That is, coming up with new products that have a link to existing products (Kamoche and Cunha 2001; Miner et al. 1997), or as in the case of Sun Microsystems, planting a directional seed from the top down to explore network computing (Moss Kanter 2002). Such a balance of template guidance and improvisation may also manifest itself as an established new product development process carried out in tandem with encouraged inclusion of improvisation (Samra et al. 2008; Song et al. 2011). Building upon a foundation of "how things are done" can result in improving the coherence and speed of actions within organizations, particularly in dynamic environments (Dewett and Williams 2007).

Whereas bounded improvisation involves improvising a novel process or product within an existing structure, structural improvisation implies improvising the very structure itself. OI can occur "within forms, with forms, and beyond forms" (Zack 2000: 227). Yet, most OI research describes improvisation within clearly defined structures. Although it involves discarding clear links to the original and coming up with something novel (Hatch 1997), radical improvisation is also rarely identified as having the capacity to transcend and redefine structures (Moorman and Miner 1998b; Zack 2000: 230). Structural improvisation does.

Structural improvisation may occur when disparate areas of an organization become linked when least expected, sometimes leading to the redefinition of the mission or business strategy (Blank 2005). An internal corporate venture group may also create a product that is inconsistent with the firm's existing strategy (Burgelman 1983), or existing organizational 
structures may be so dramatically shaken by a crisis that they have to be subsequently discarded (Rerup 2001; Weick 1993b).

\section{Levels of Improvisation: Individual, Interpersonal and Organizational}

Whereas the minor, bounded and structural degrees of improvisation represent a continuum, the individual, interpersonal and organizational levels of improvisation are distinct from one another. The typology borrows from the organizational learning terminology of individual, group and organizational levels (Argyris and Schön 1978; Nonaka and Takeuchi 1995). This three-way classification has proved useful in other fields, including organizational creativity (Woodman et al. 1993) and knowledge management (Nonaka and Konno 1998). As within these other fields, OI research initially focused on the individual level before expanding towards the interpersonal and organizational levels (Miner et al. 2001). Ultimately, an organization is responsible for the provision of the right culture and environment to promote product innovation (De Tienne and Mallette 2012), spontaneity and simultaneous consciousness (Soules 2002), and desired amounts of improvisation at the individual, interpersonal and organizational levels (Seelig 2012).

Individual improvisation happens in organizations when employees adjust their work in real time to emerging information or are stretched beyond their routines to deliver a novel solution to a problem. Team-level antecedents, such as team behavioral integration and cohesion, influence the process of resource exchange among individual team members, and consequently positively affect individual improvisation too (Magni et al. 2009). New information technologies increase the scope of individual improvisation, and the Internet provides entrepreneurial improvisers with a global reach in real time (Kao 1996b). A predisposition to engage in improvisation within the organization denotes a positive individual attitude toward improvisation (Magni et al. 2010). Yet, improvisation is not inherently a positive individual attribute: "field observations [make] clear that improvisation can also be unskilled and can cause harm" (Miner et al. 2001: 329; Pavlou and El Sawy 2010).

The image of an improvising jazz soloist is generally used to illustrate OI - so much so that large parts of the literature focusing on organizational aspects of improvisation underline the individual's freedom to improvise and tinker within the organization. Creative improvisation rarely flows from simply "trying harder" (Werner 1996). Individuals always bring their backgrounds and memories into the improvisation (Crossan and Sorrenti 2002; Cunha et al. 1999). They learn to improvise by understanding the purpose behind a process, 
and then reconsidering this process itself: "What's the message for business people who want to improvise better? Take some skill that you have mastered and unlearn it" (Mirvis 1998: 587).

Interpersonal improvisation transcends the individual level and takes place in small teams where real-time adjusting and responding is bi- or multilateral. Collective improvisation often happens interpersonally, without the whole organization joining in. The stimuli of others enable teams to brainstorm new ideas that no member could have developed alone (Sutton and Hargadon 1996), and experimental skunk-works teams can piece together novel solutions from parts all around the organization (Moorman and Miner 1998a). Information technologies can promote interpersonal improvisation by helping to overcome physical distances (McKnight and Bontis 2002). Just like individual improvisation however, interpersonal improvisation is not always "mindful", and may be marred by cognitive errors (Vuori and Vuori 2014; Bingham and Eisenhardt 2014).

Interpersonal improvisation also happens in jazz bands and improvisation leagues, for instance when the drummer picks up and responds to the saxophonist's idea, or when an actor agrees to another's offer and builds on it (respectively).

Organizational-level improvisation refers both to the ability of the whole organization to improvise and to the institutionalization of structures or practices that enable or lead to improvisation within the organization. Although labeling one specific type of OI as "organizational-level" might sound confusing in the eponymous field, this terminology is correct: OI is improvisation by an organization or its members.

Organizational-level improvisation: "contributes to and is an outcome of organization absorptive capacity for new knowledge, structural flexibility, market flexibility, operational flexibility, intrapreneurial culture and of the organization path dependence of exploitation and exploration adaptations" (Lewin 1998: 539). Organizational-level improvisation may be an aggregation of individual improvisations or a fundamentally collective and seamless process (Miner et al. 2001). When a jazz band improvises organizationally, the whole unit develops extemporaneous ideas in new, emerging ways. In mainstream jazz, pianist Bill Evans's egalitarian "first great trio" (1959 to 1961) pioneered organizational-level improvisation, where all could break their instruments' conventions and improvise as a single, organic unit. 


\section{The Degree/Level Framework of Organizational Improvisation}

The degree/level framework introduced in Table 2 synthesizes the above discussion and accounts for the complexity and variety of improvisation modes within organizations. It is a novel attempt to make sense of OI and to identify future research areas. The degree/level framework is distinct from existing classifications in three ways: it requires limited technical knowledge; it makes clear distinctions that allow simple ordinal classification; and it transcends metaphors, organizational settings and industry environments. To this third point and inasmuch as it accommodates all the metaphors used in OI research and all the studies carried out in naturalistic settings, the framework allows for the first comprehensive mapping of the OI literature across disciplines and research areas.

Several studies of OI elaborate on the full range of degrees (e.g., Cunha et al. 1999; Kamoche et al. 2003; Moorman and Miner 1998a, 1998b; Zack 2000) or levels (e.g., Crossan et al. 2005; Lewin 1998; Vera and Crossan 2005) of OI. Yet, very few explicitly incorporate both. Some state that they do not differentiate between different types of OI (Magni et al. 2008), and many give no particular thought to the matter. Accordingly, assigning all 197 contributions into particular cells in the framework would be in large part unfeasible although some of their findings may be classified more readily. Each of the nine cells detailed in more detail below represents a different type of OI, and is labeled with a title derived from the existing OI literature.

\section{Insert Table 2 about here}

\section{Minor/individual: "Spontaneous practice"}

Spontaneous practice occurs when an individual improvises within an existing process. With creativity and innovation becoming major issues in mainstream management (Hamel and Breen 2007), organizations can train managers and employees to be spontaneous (Vera and Crossan 2004), and workers have increasing leeway to engage in minor improvisation and extemporaneously perform given tasks differently. Such spontaneous action requires a high level of competence that often comes from practice and experience. Rather than spontaneous practitioners, these improvisers are consequently described as spontaneous practicers (Berliner 1994; Weick 1998).

Although easy to comprehend conceptually, the minor/individual form of improvisation is actually extremely complex and hard to implement in practice. Spontaneous practicers, by definition, find themselves in no position to feed off the work of others and 
improvise off their offers. They are akin to performers left alone on stage to improvise in front of an audience.

\section{Bounded/individual: "Expert leadership"}

Expert leaders improvise completely novel actions within the confines of existing organizational structures (Barrett and Peplowski 1998). This type of improvisation is best suited to situations where experts are given an objective and autonomy to reach it through any means necessary. Other organizational members are given little room for creativity outside the expert leader's core objective. Expert leaders are sometimes described as "wartime CEOs", and come into their own when their organization struggles to fend off imminent existential threats: for instance, disruptive changes to the industry (Horowitz 2014). Andy Grove's drive to move Intel away from the fast-commoditizing memory business (Grove 1996) and Steve Jobs's return to Apple when it was on the brink of bankruptcy (Isaacson 2011) provide illustrations of expert leadership improvisation.

A common picture painted in IO research is of a lone jazz soloist improvising musical phrases in the spotlight before an accompanying orchestra/organization. The bebop era featured virtuosic individual soloists whose improvisation was principally bounded. Lone actors and dancers improvising new dialogue or movement in the spotlight before their company during a live performance also act as expert leaders.

\section{Structural/individual: "Dropping tools"}

Individual actors may go beyond improvising the way of performing a given task to break free from existing organizational structures and "drop [their] tools" (Weick 1996). Structural/individual improvisation takes place irrespective of the organizational context and is inherently uncontained. When the approaching Mann Gulch wildfire overcame the efforts of 16 firefighters, smokejumper Wagner Dodge surprisingly broke from the known structure of firefighting and ordered his 15 colleagues to "drop your tools" (Weick 1993b: 635). Refusing to follow, 13 of these firemen died, whereas Dodge spontaneously improvised an escape fire that saved his life. US Airways Captain Chesley Sullenberger's emergency landing of a commercial flight into the Hudson River in January 2009 after both plane engines were incapacitated by a flock of birds provides another organizational illustration of dropping tools (Pavlou and El Sawy 2010). In the performing arts, jazz pianist Keith Jarrett and French actor Fabrice Luchini are also famous for individually improvising structures during their live shows. 


\section{Minor/interpersonal: "Synchronization"}

Synchronization occurs when team members become particularly attuned and sensitive to one another's actions and reactions as they collectively adjust or apply existing processes or solutions in new ways. Synchronization is sometimes termed "peak performance" (Gilson et al. 2001) or "flow" (Csikszentmihalyi 1990; Marotto et al. 2007). It translates into repeat wins for the best sports teams (Gilson et al. 2001), and those moments of collective virtuosity displayed by classical orchestras that are impossible to quantify and difficult to describe without resorting to subjective criteria (Marotto et al. 2007).

The concept of synchronization comes directly from music. It describes the process of tuning in, which is sometimes described in organizational change as "the groove" (Barrett 1998, 2000, 2012; Barrett and Hatch 2003). The groove describes the rhythmic synchronization of instrumentalists, particularly in jazz between the bassist and drummer. Such rhythmic synchronization forms the bedrock of the music, and requires ongoing microlevel interpersonal adjustment and sensitivity to the relevant organizational partner(s).

\section{Bounded/interpersonal: "Yes-and"}

The "yes-and" rule of improvisation is known across performing arts and is the most popular OI concept derived from improvisational theatre. It consists in unconditionally accepting ("yes") and building on ("and") improvisational offers from others. Yes-anding is interpersonal, since it describes one individual's response to another's initiative. It is also bounded, since the very principle of yes-anding acts as a minimal structure that frames the improvisation without being subject to it (Crossan 1997, 1998; Crossan et al. 1996; Vera and Crossan 2004, 2005; also in Koppett 2002; McKnight and Bontis 2002; Meyer 2005).

Evidence of yes-anding abounds in improvisational jazz and comedy. For instance, the HBO long-running hit comedy "Curb Your Enthusiasm" (2000-2011) is famous for its absence of script: actors were only given a few loose guidelines, and were encouraged to improvise in a context of "planned spontaneity" (Pavlou and El Sawy 2010).

\section{Structural/interpersonal: "Minimal Structuring"}

Minimal structuring provides managers and employees with a paradoxical combination of guidance and permission (Sonenshein forthcoming) or of rigidity and freedom (Cunha et al. 2009): "This combination provides space for creative approaches to emerge, while guaranteeing focus and countering drift" (Cunha et al. 2009: 665). A set of big, immutable rules (namely, goals and responsibilities) clarifies what is non-negotiable, while also giving 
employees flexibility to improvise, self-organize and creatively solve problems (Sonenshein forthcoming). Semi-structures also provide a form of minimal structuring that enables high performance through the combination of both efficiency via repeatability and flexibility via enabling real-time adaptation through improvisation. They allow systems to poise at the "edge of chaos", a dissipative equilibrium between too much and too little structure (Bingham and Eisenhardt 2014).

Research on structural/interpersonal improvisation highlights the key role of managers as sense-givers (Plowman et al. 2007; Sonenshein forthcoming). It shows that interactions among organizational members and managers mold structures (Plowman et al. 2007), interactions between people and structures shape and generate the resources needed for creativity (Sonenshein forthcoming), and interactions between employees and clients inside structures may be used as tools for improvising (Cunha et al. 2009). Managers who build and sustain high-quality connections based on mutual positive regard, trust, and active engagement on both sides with colleagues, supervisors, subordinates and customers also have a profound impact on an organization's energy levels and capacity for collaboration, coordination, learning and adaptation (Dutton 2003).

Embracing equivocality (that is, acknowledging that there is no single right answer to problems) is a prerequisite to minimal structuring, which: "assumes an aesthetics of imperfection, meaning the acceptance of honest mistakes, less than perfect planning, and emergence" (Cunha et al. 2009: 662). To allow minimal structuring, the management team needs to adopt a hands-off stance, and let employees experiment with ideas and test heterogeneous solutions (Sonenshein forthcoming). Improvisers need to be action-oriented, quick to react and encouraged to act on the spot using available resources (Plowman et al. 2007; Cunha et al. 2009; Sonenshein forthcoming). Mutual accountability must prevail over individual responsibility (Cunha et al. 2009).

Minimal structuring characterizes improvisation in the form of creative resourcing at BoutiqueCo both in resource-constrained and resource-substantial periods (Sonenshein forthcoming). Minimal structuring is also at play in Mission Church's continuous radical change from a declining silk-stocking to a diverse congregation, which occurred through the interplay of small changes (starting with the initial simple act of offering breakfast to the homeless), amplifying actions (including the opening of a medical clinic and the use of language, symbols and signals to reinforce the church's commitment to its new emerging vision), and contextual conditions of initial organizational decline, changes in leadership, identity struggles and ongoing organizational conflict (Plowman et al. 2007). 
Highly effective service recovery (Cunha et al. 2009) and Saatchi \& Saatchi's internal definition of creativity as: "stretching the walls of the elastic-sided sandbox" provide other illustrations of minimal structuring. In jazz, any pair of musicians in Miles Davis's 1963-68 quintet could jump out of the existing harmonic structure and improvise a new one interpersonally, without the greater organization necessarily departing from the initial harmonic structure.

\section{Minor/organizational: "Space for experimenting"}

Many organizations have moved away from mechanistic, top-down approaches of management to define structures more loosely, encourage novel ways of performing routine tasks, and create space for experimenting. Equipping organizations with "internal market information" can increase the odds of building new ideas with greater customer value and market success (Kyriakopoulos 2011; Olson et al. 1995). Communities-of-practice also regularly modify work practices within and around organizations (Brown and Duguid 1991).

Organizations may give employees space to explore their creativity by working on their projects differently (Hamel and Breen 2007), for instance by granting "slack capacity" (Damanpour 1991; Rosner 1968) in employees' work routines to allow for creative experimenting and "jamming" with ideas (Grayson et al. 2014; Kao 1996a). Google employees are encouraged to devote some of their time to pursuing new projects, IBM launched a series of "global jam sessions" inspired by Kao (2006a), and increasing numbers of organizations stage Lego® Serious Play® workshops (Hadida 2013). The more organizations practice with improvisation, the stronger they become at it (Leonard-Barton and Leonard 1995).

\section{Bounded/organizational: "Constrained improvisation"}

Meaningfully-constrained improvisation is defined as extemporaneous improvisation performed with a clear understanding of, respect for and allegiance to the structures and objectives of the organization (Bigley and Roberts 2001). ${ }^{4}$ Constrained improvisation is aligned to the organization's goals, and inherently contained. Freelancing, which is perceived as detrimental to organizational effectiveness and goal completion, is socially sanctioned. Constrained improvisation relies on good communication within the organization, and on striking the right balance between top-down pre-planned, explicit and centralized structuring mechanisms developed to meet most contingencies at corporate level and bottom-up, emergent and more diffuse improvisation and local accommodation to address the unforeseen 
at task level (Bigley and Roberts 2001; Brady 2011). In situations where resources are in short supply, circumstances are changing rapidly and communication may be difficult, preparedness and improvisation constitute the twin foundations of crisis response (Drabek and McEntire 2002).

Toyota's NUMMI assembly plant (Adler et al. 1999), the Incident Command System (ICS) of a large California fire department (Bigley and Roberts 2001) and the Russian Army during the battle of Stalingrad (Brady 2011) provide illustrations of constrained improvisation. Model changeovers exemplify the high levels of bureaucracy and flexibility displayed at the NUMMI plant, where organizational flexibility increases through the transformation and expansion of traditional bureaucratic structures (Adler et al. 1999). Similarly, the highly bureaucratic ICS encourages improvisation with tools (to optimally use the limited resources available in the trucks), rules (when violations of standard operating procedures are needed), and routines (which sometimes need to be adjusted to accommodate local circumstances) in unforeseen, turbulent, time constrained and hazardous circumstances (Bigley and Roberts 2001).

Just as ICS supervisors provide their subordinates with a degree of latitude to improvise, coordinate their own routines and address unexpected problems on the ground, General Vassily Chuikov relaxed the hierarchical command and control structure of the Russian army in Stalingrad to combine formal structure (planned action) and improvisation (adaptive reaction to events as they unfold) at the front line. Heedful interactions through storytelling and personal examples of exceptional bravery contributed to morale and rapid socialization of new troops. A series of tactical improvisation moves combining active defense, hugging the enemy to prevent aerial attacks, and sniper and small storm-group attacks also helped the Russian army regain ground and create a permanent state of strain and fear in their German enemy (Brady 2011). In music, chord changes within songs illustrate constrained improvisation (Barrett and Peplowski 1998).

\section{Structural/organizational: "Platform organization"}

A platform organization possesses a "readiness to sport whatever organizational form is required under the circumstances" (Ciborra 1996: 103). It is "a virtual organizing scheme, collectively shared and reproduced in action by a pool of human resources, where structure and potential for strategic action tend to coincide in highly circumstantial ways" (Ciborra 1996: 115). A platform organization may consequently opportunistically pursue any emerging business opportunities (Ciborra 1996). In practice, structural/organizational 
improvisation may still be rare in established organizations. Even so, entrepreneurial ad hoc teams, nimble virtual organizations, open innovation systems and flexi-time have made platform organizations viable.

The jazz metaphor (in particular, free jazz) provides multiple opportunities to illustrate the ambiguous, emotional and temporal characteristics of platform organizations (Hatch 1999; Holbrook 2007; Kamoche and Cunha 2001; Zack 2000): "Where antecedents, influences and outcomes interact simultaneously, as in free jazz, a structuration perspective (Ranson et al. 1980) might be more appropriate" (Kamoche et al. 2003: 2027).

\section{$\underline{\text { Discussion and Conclusions }}$}

Our understanding of OI has gone a long way since this concept was first dismissed by managerial planning (Taylor 1911) and formal strategizing (Chandler 1962). After Cunha's et al. (1999) review, new approaches to OI have emerged. They propose new metaphors, more precise and numerous empirical investigations of OI (most notably, in new product development: e.g., Akgun and Lynn 2002; new ventures: e.g., Hmieleski and Corbett 2008; and new conditions of change and turbulence: e.g., Charles and Dawson 2011), and a greater emphasis on conceptually rigorous methodologies based on in-depth case studies and interviews (e.g., Mendonca and Wallace 2004; Plowman et al. 2007; Sonenshein forthcoming).

This article set out to review existing knowledge of OI and consolidate it in a novel and comprehensive framework combining degrees (minor, bounded, and structural) and levels (individual, interpersonal, and organizational) of OI. The degree/level framework reconciles metaphorical, empirical and anecdotal OI studies, and allows for a systematic review of existing contributions in strategy, organizational behavior, organizational theory, innovation, and marketing. As such, it introduces a taxonomy that accounts for the various forms of improvisation that take place in organizations. By explicitly categorizing types of OI, the degree/level framework illustrated in Table 2 also aims to help researchers deal with the richness and extensiveness of this process.

Our efforts to define and illustrate the degrees and levels of OI and to assign their combinations to one of the nine cells of the proposed degree/level framework contribute to unveiling the complexity and vibrancy of improvisation in organizations. Perhaps counterintuitively, we also hope that they help emancipate this concept from all limiting semantic yokes. Take the often-made assumption, for instance, that OI may be "inherently uncontained", previously mentioned in this article. Our analysis demonstrates that this is not 
true of all types of OI delineated in the literature and in the degree/level framework. In fact, OI is much more dynamic and multifaceted than most contributions give it credit for, and manifests itself in processes that range from inherently contained (e.g., constrained improvisation) to inherently uncontained (e.g., dropping tools).

As OI research evolves, we anticipate an increase in studies exploring and analyzing the situations described in the nine cells of the framework. We also expect the boundaries of what is and is not legitimately included in the degree/level framework to be tested, stretched and revisited to include new forms and dimensions of improvisation as they emerge within organizations. Two sets of limitations of existing OI research and by extension, of the proposed degree/level framework provide a roadmap for future OI research.

First, existing OI research categorized in the degree/level framework (Table 2) offers a static picture of the various degree/level combinations. Very few studies explain, for instance, how and why organizational members learn and evolve from improvising alone (individual) to improvising with one or few others (interpersonal) and onto improvising with a whole organization (organizational-level). Nor do they offer a detailed approach to how and why individuals, teams and organizations progress from improvising how existing tasks are performed (minor) to improvising new tasks within existing structures (bounded) and onto improvising beyond existing structures (structural). As such, existing research does not explain whether cells operate as necessary precursors to one another, or whether shortcuts or diagonal "jumps" in the framework (e.g., from minor/individual straight to bounded/interpersonal) are achievable and sensible. Similarly and as already pointed out by Magni et al. (2009), very few studies analyze the influence of antecedent variables at one level (e.g., interpersonal) on improvisation at another level (e.g., individual).

In future research, we advocate the development of more cross-level analyses of OI. In particular, we recommend investigating evolutionary and learning paths that allow individuals, teams and organizations to move from one cell to another in the framework and determining desirable paths across degrees and levels of OI. The actual desirability of intercell movements may also depend on individual, interpersonal and organizational contexts and circumstances on the one hand, and on the nature of improvisation tasks on the other. Systematically investigating such moderating effects of OI offers an additional direction for future studies, particularly with regards to leadership and followership.

Thus, although existing research has identified positive influences of OI on leadership (e.g., Bastien and Hostager 1988; Gagnon et al. 2012; Newton 2004; Vera and RodriguezLopez 2007), it has not investigated so far the relationship between the mental models of 
leaders and OI. An analysis of the nine cells in Table 2 with a focus on mental models could shed new light on OI. For instance, leaders and managers may perceive surprise as "an opportunity for creativity" and improvisation or as "an indication of poor control" and "a stimulus for finger pointing and blaming” (Plowman et al. 2007: 540). Their tolerance for surprise, in other words, may condition the degree and level of improvisation permitted and the success or failure of its outcome within the organization.

At the other end of the leadership spectrum, the role of audience engagement in the OI process and in the success or failure of its outcome begs particular attention. At the end of a concert, conductor Benjamin Zander customarily gives a round of applause to audience members, whom he sees as active co-creators of his orchestra's live performance (Zander and Zander 2000). In the context of OI, audiences may consist internally of one or several coworkers, and externally of partner organizations (e.g., suppliers and distributors) and other stakeholders (e.g., competitors, consumer groups, industry experts and regulators). So far, the OI literature has paid little attention to these constituents.

This may be an indirect consequence of its emphasis on the jazz metaphor. Since theatre audiences speak the (verbal) language of the improvisers, audience engagement may be seen as more of a prominent feature in theatrical improvisation than in jazz improvisation. In mainstream jazz concerts and festivals, often only a fraction of the audience speaks the (musical) language of the improvisers. Conversely, in jam sessions at jazz clubs where most of the audience is composed of fellow musicians, the sense of audience feedback may be just as prominent as in theatrical improvisation.

Improvisers feed off the energy, attention levels and reactions of their audience. The degree/level framework does not exist in a vacuum: levels of improvisation change depending on who is witnessing the improvisation process, and how at ease the improvisers are. Thus, three individuals improvising on their own will lead to very different outcomes from three individuals improvising together, with 100 friends, or with 100 co-workers (for instance). The audience, be it defined as co-workers watching an "expert leader" improvising processes or products in the spotlight, project leaders observing their teams as they "synchronize", or scholars documenting "platform organizations", can play an important role in nurturing or hindering OI. More specific illustrations and empirical tests may lead to the inclusion of a new audience engagement dimension in the degree/level framework.

We therefore propose, as a second suggestion for further research, to investigate the role of moderating effects - in particular, leaders' and managers' mental models and audience engagement - as important components of the improvisation process and 
influencers of its outcome. This analysis should also be carried out on the nine cells of the degree/level framework and in the context of inter-cell movements.

We encourage researchers across disciplines to join us in our efforts to shed light on OI, and to use the consolidating degree/level framework to better understand this important and complex organizational phenomenon. The framework also provides a template to assist in thinking about how expected improvisational dynamics may evolve as organizations change over time. In the aftermath of the 2008 economic crisis, most organizations still find themselves severely constrained in their access to resources, and under pressure to make the most of their members in creative and cost-efficient ways. We therefore also encourage leaders, managers and employees to use the degree/level framework as a dynamic analytical and diagnostic tool to help create conditions for successful improvisation in organizations and select the degree and level of improvisation most suitable to their specific and evolving contexts and circumstances. 
Figure

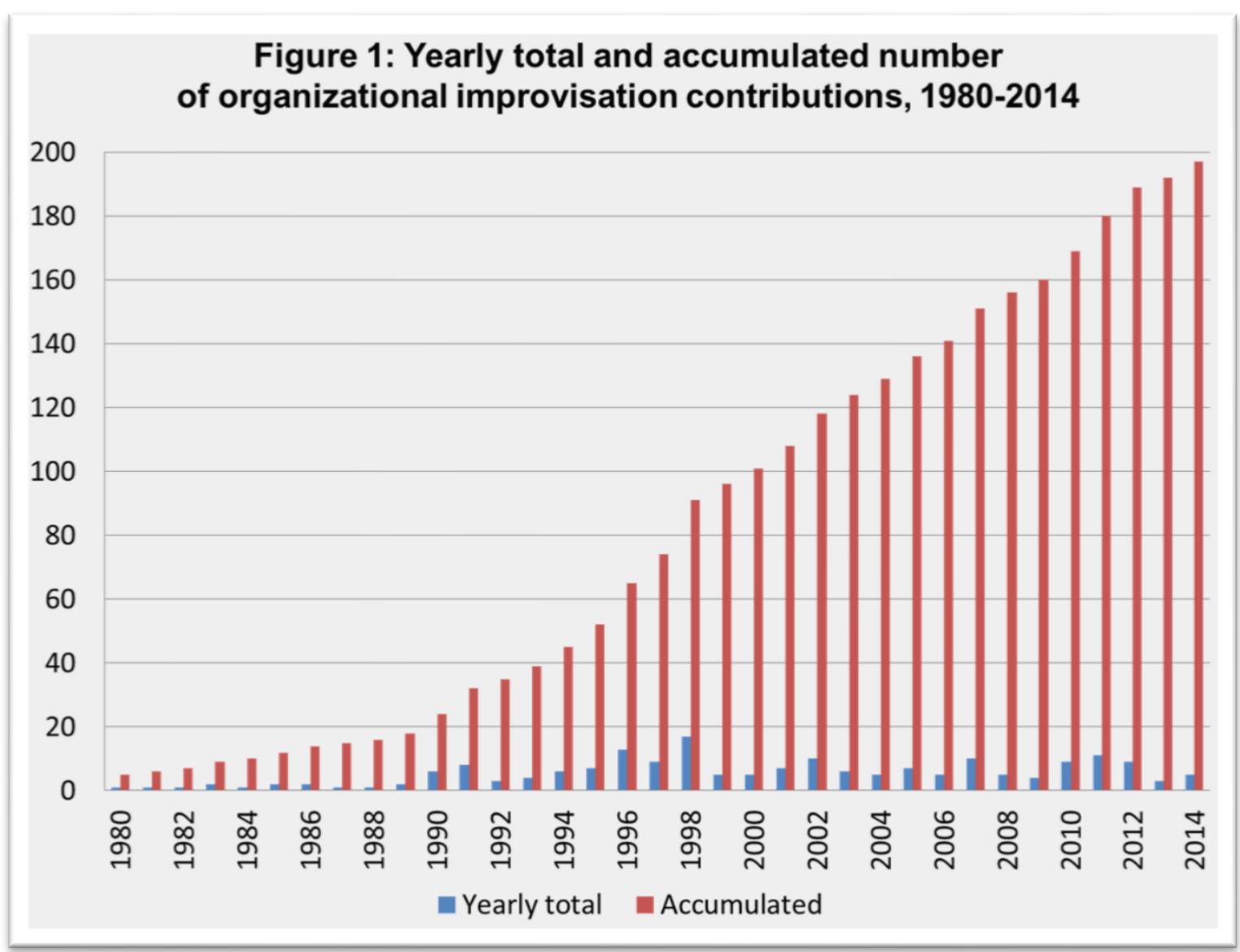


Tables

\section{Table 1: Existing Definitions of Organizational Improvisation}

\section{Source}

Improvisation described as...

Primary level of improvisation: Individual

Balachandra et al. (2005)

Barrett (1998)

Barrett (2000)

Barrett and Peplowski (1998)

Brown and Eisenhardt (1997)

Cleary and Groer (1994)

Crossan et al. (1996)

Gardner and Rogoff (1990)

Hmieleski and Corbett (2008)

Leybourne and Sadler-Smith (2006)

Lockford and Pelias (2004)

Machin and Carrithers (1996)

Magni et al. (2009)

Meyer (1998)

Mirvis (1998)

Pasmore (1998)

Tanenbaum and Tanenbaum (2008)

Weick (1993b)

Weick (1998)

Weick (2001)

Dealing with the unexpected; Responding "in the moment"; Adapting effectively to sudden changes

Inventing novel responses without a plan; Discovering the future as action unfolds

Contemporaneous composition and performance

Creating on the spot without a pre-scripted plan

Making strategy up as one goes along

Making numerous interactive in-flight decisions (psychology)

Primary level of improvisation: Interpersonal

Akgun et al. (2007)

Charles and Dawson (2011)

Crossan $(1997,1998)$

Magni et al. (2008)

Ideas emerging in un-planned ways; Taking advantage of opportunities in the moment

Adapting planning to the circumstances (psychology)

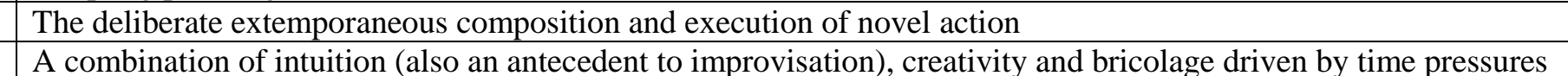

Incorporating new information spontaneously to action; Adapting to emergent circumstances (theatre)

Creating ad hoc responses according to circumstances (anthropology)

The creative and spontaneous behavior of managing an unexpected event

Solving problems in the nick of time

Making things up as one goes along

Creating in real time in a flexible fashion

A highly contingent and emergent human process (theatre)

Immediately inventing substitutes to old order

Dealing with the unforeseen without prior stipulation

Just-in-time strategy

McKnight and Bontis (2002)

Planning and executing an action simultaneously; Condition by which composition and execution converge in time

Situated action in making sense of contextual circumstances in emergent problem-solving

Intuitive and spontaneous action

Sharron (1983)

The creative and spontaneous process of managing an unexpected event

Spontaneously recombining knowledge, processes and structure in real time

Immediate and spontaneous creation process (sociology) 
Primary level of improvisation: Organizational

\begin{tabular}{|c|c|}
\hline Baker et al. (2003) & Convergence of design and execution of novel activities or action \\
\hline Barrett and Hatch (2003) & Continuous elaboration of the absolutely new \\
\hline Bastien and Hostager (1988) & Inventing new ideas as performance unfolds over time \\
\hline Bergh and Lim (2008) & $\begin{array}{l}\text { Short-term learning where experience and related change occur at or near the same time and that applies to novel, } \\
\text { fast and uncertain actions and decisions. Improvisers draw from information and resources available (bricolage) }\end{array}$ \\
\hline Chelariu et al. (2002) & Unplanned yet purposeful response to a turbulent, fast changing environment \\
\hline Ciborra (1996) & Structure and strategy coincide in highly circumstantial ways \\
\hline Ciborra (1999) & Extemporaneous process \\
\hline Crossan and Sorrenti $(1997 ; 2002)$ & Intuition guiding action in a spontaneous way \\
\hline $\begin{array}{l}\text { Cunha et al. }(2003) \\
\text { Cunha } \text { et al. }(2009)\end{array}$ & Conception of action as it unfolds, drawing on available resources (bricolage) \\
\hline Hatch $(1998,1999)$ & Playing around and with a structure \\
\hline Hutchins (1991) & Action emerging without planning \\
\hline Kamoche and Cunha $(1997,2001)$ & Contemporaneous composition and performance \\
\hline King and Ranft (2001) & Combining adhockery with know-how \\
\hline Miner et al. (1997) & Spontaneous and novel actions \\
\hline Miner et al. (2001) & Deliberate and substantive fusion of the design and execution of a novel production \\
\hline Moorman and Miner (1995) & Extemporaneous action \\
\hline Moorman and Miner (1998a, 1998b) & Contemporaneous composition and performance \\
\hline Orlikowski and Hofman (1997) & Responding to spontaneous departures and opportunities through local innovations \\
\hline Pavlou and El Sawy (2010) & $\begin{array}{l}\text { A repeatable capability for frequent and endemic change enhanced with practice and manifested in improvisational } \\
\text { capabilities (the purposeful ability to spontaneously reconfigure existing resources to build new operational } \\
\text { capabilities to address urgent, unpredictable, and novel environmental situations) }\end{array}$ \\
\hline Perry (1991) & Formulating and implementing together in real time \\
\hline Vera and Crossan (1999) & Reworking (pre-composed) material, influenced by unanticipated factors \\
\hline Webb and Chevreau (2006) & Performing activities in non-routine or unexpected ways \\
\hline Weick (1993a) & Continuous reconstruction of processes and designs \\
\hline Zack (2000) & [Improvising] within forms, with forms, and beyond forms \\
\hline Zheng et al. 2011 & $\begin{array}{l}\text { Simultaneous conception and execution (real-time planning); Finding solutions from available rather than optimal } \\
\text { resources (bricolage) }\end{array}$ \\
\hline \multicolumn{2}{|l|}{ No primary level of improvisation } \\
\hline Berliner (1994) & A way of life; reworking (pre-composed) material, influenced by unanticipated factors (musicology) \\
\hline Crossan et al. (2005) & Convergence of composition and execution; Conception of action as it unfolds \\
\hline
\end{tabular}




\begin{tabular}{|l|l|}
\hline Cunha et al. (1999) & Conception of action as it unfolds \\
\hline Holbrook (2007) & Responding quickly, flexibly, and self-reflexively to changes \\
\hline Kao (1996a, 1996b) & Jamming with an idea to create something novel \\
\hline Lewin (1998) & Human capital flexibility \\
\hline Peplowski (1998) & Painting oneself in a corner just to get out of it, inspiration in mistakes \\
\hline Schuller (1968) & Playing extemporaneously, without the benefit of written music, in the spur of the moment (musicology) \\
\hline Vera and Crossan (2005) & The creative and spontaneous process of trying to achieve an objective in a new way \\
\hline
\end{tabular}


Table 2: The Degree/Level Framework of Organizational Improvisation

\begin{tabular}{|c|c|c|c|c|}
\hline & & One $\leftarrow$ & LEVEL & $\rightarrow$ Many \\
\hline & & Individual & Interpersonal & Organizational \\
\hline Minor & Minor & $\begin{array}{c}\text { Spontaneous practice } \\
\text { (Weick 1998) }\end{array}$ & $\begin{array}{c}\text { Synchronization } \\
\text { (Barrett 1998) }\end{array}$ & $\begin{array}{c}\text { Space for } \\
\text { experimenting } \\
\text { (Kao 1996a) }\end{array}$ \\
\hline DEGREE & Bounded & $\begin{array}{l}\text { Expert leadership } \\
\text { (Barrett \& } \\
\text { Peplowski 1998) } \\
\end{array}$ & $\begin{array}{c}\text { Yes-and } \\
(\text { Crossan 1998) }\end{array}$ & $\begin{array}{c}\text { Constrained } \\
\text { improvisation } \\
\text { (Bigley \& Roberts 2001) }\end{array}$ \\
\hline $\begin{array}{c}\downarrow \\
\text { Major }\end{array}$ & Structural & $\begin{array}{l}\text { Dropping tools } \\
\text { (Weick 1993b) }\end{array}$ & $\begin{array}{l}\text { Minimal structuring } \\
\text { (Plowman et al. 2007) }\end{array}$ & $\begin{array}{c}\text { Platform organization } \\
\text { (Ciborra 1996) }\end{array}$ \\
\hline
\end{tabular}




\section{References}

Adler, P.S., Goldoftas, B. and Levine, D.I. (1999). Flexibility Versus Efficiency? A Case Study of Model Changeovers in the Toyota Production System. Organization Science, 10, pp. 43-68.

Akgun, A.E. and Lynn, G.S. (2002). New Product Development Team Improvisation and Speed-to-Market: An Extended Model. European Journal of Innovation Management, 5(3), pp. 117-129.

Akgun, A.E., Byrne, J.C., Lynn, G.S., and Keskin, H. (2007). New Product Development in Turbulent Environments: Impact of Improvisation and Unlearning on New Product Performance. Journal of Engineering and Technology Management, 24, pp. 203-230.

Ansoff, H.I. (1991). Critique of Henry Mintzberg's 'The Design School: Reconsidering the Basic Premises of Strategic Management'. Strategic Management Journal, 12(6), pp. 449-461.

Aram, J.D. and Walochick, K. (1996). Improvisation and the Spanish Manager. International Studies of Management and Organization, 26(4), pp. 73-89.

Argyris, C. and Schön, D. (1978). Organizational Learning: A Theory of Action Perspective. Reading, MA: Addison-Wesley.

Bailey, D. (1992). Improvisation: Its Nature and Practice in Music. New York: Da Capo Press.

Baker, T., Miner, A.S. and Eesley, D.T. (2003). Improvising Firms: Bricolage, Account Giving and Improvisational Competencies in the Founding Process. Research Policy, 32, pp. 255-276.

Baker, T. and Nelson, R.E. (2005). Creating Something from Nothing: Resource Construction through Entrepreneurial Bricolage. Administrative Science Quarterly, 50(3), pp. 329-366.

Balachandra, L., Crossan, M., Devin, L., Leary, K. and Patton, B. (2005). Improvisation and Teaching Negotiation: Developing Three Essential Skills. Negotiation Journal, October, pp. 435-441.

Barreto, M.A. and Ribeiro, S.L.O. (2012). Aircraft Accident Investigation: The DecisionMaking in Initial Action Scenario. Work, 41, pp. 4931-4935.

Barrett, F.J. (1998). Creativity and Improvisation in Organizations: Implications for Organizational Learning. Organization Science, 9(5), pp. 605-622. 
Barrett, F.J. (2000). Cultivating an Aesthetic of Unfolding: Jazz Improvisation as a SelfOrganising System. In Linstead, S. and Hopfl, H.J. (eds.). The Aesthetics of Organizations. London, UK: SAGE Publications, pp. 228-245.

Barrett, F.J. (2012). Yes to the Mess: Surprising Leadership Lessons from Jazz. Boston, MA: Harvard Business School Publishing.

Barrett, F.J. and Cooperrider, D.L. (1990). Generative Metaphor Intervention: A New Approach for Working with Systems Divided by Conflict and Caught in Defensive Perception. Journal of Applied Behavioral Science, 26(2), pp. 219-239.

Barrett, F.J. and Hatch, M.J. (2003). Planning on Spontaneity: Lessons from Jazz for a Democratic Theory of Change. Academy of Management, Best Conference Paper 2003 in Organizational Development and Change, D1-D6.

Barrett, F.J. and Peplowski, K. (1998). Minimal Structures within a Song: An Analysis of 'All of Me'. Organization Science, 9(5), pp. 558-560.

Bastien, D.T. and Hostager, T.J. (1988). Jazz as a Process of Organizational Innovation. Communication Research, 15(5), pp. 582-602.

Bathurst, R.J. and Williams, L.P. (2013). Managing Musically: How Acoustic Space Informs Management Practice. Journal of Management Inquiry, 22(1), pp. 38-49.

Bergh, D.D. and Lim, E.N-K. (2008). Learning How to Restructure: Absorptive Capacity and Improvisational Views of Restructuring Actions and Performance. Strategic Management Journal, 29, pp. 593-616.

Berliner, P.F. (1994). Thinking in Jazz: The Infinite Art of Improvisation. Chicago, IL: University of Chicago Press.

Berniker, E. (1998). Working the Jazz Metaphor: Musings Driving Down 1-5 Past Midnight. Organization Science, 9(5), pp. 583-585.

Bernstein, A. (2000). How Can Cooperative Work Tools Support Dynamic Group Processes? Bridging the Specificity Frontier. In Proceedings of the Conference on Computer Supported Cooperative Work, Philadelphia, PA: ACM Press.

Bigley, G.A. and Roberts, K.H. (2001). The Incident Command System: High Reliability Organizing for Complex and Volatile Task Environments. Academy of Management Journal, 44(6), pp. 1281-1299.

Bilton, N. (2012). A Master of Improv, Writing Twitter's Script. The New York Times, 6 Oct. Bingham, C.B. and Eisenhardt, K.M. (2011). Rational Heuristics: The 'Simple Rules' that Strategists Learn from Process Experience. Strategic Management Journal, 32, pp. 1437-1464. 
Bingham, C.B. and Eisenhardt, K.M. (2014). Heuristics in Strategy and Organizations: Response to Vuori and Vuori. Strategic Management Journal, in press.

Blank, S.G. (2005). The Four Steps to the Epiphany: Successful Strategies for Products that Win. Cafepress.com.

Brady, M. (2011). Improvisation versus Rigid Command and Control at Stalingrad. Journal of Management History, 17(1), pp. 27-49.

ten Brinke, W.B. M., Kolen, B., Dollee, A., van Waveren, H. and Wouters, K. (2010). Contingency Planning for Large-Scale Floods in the Netherlands. Journal of Contingencies and Crisis Management, 18(1), pp. 55-69.

Brown, J.S. and Duguid, P. (1991). Organizational Learning and Communities-of-Practice: Toward a Unified View of Working, Learning and Innovation. Organization Science, 2(1), pp. $40-57$.

Brown, S.L. and Eisenhardt, K.M. (1997). The Art of Continuous Change: Linking Complexity Theory and Time-Paced Evolution in Relentlessly Shifting Organizations. Administrative Science Quarterly, 42(1), pp. 1-34.

Burgelman, R.A. (1983). A Process Model of Internal Corporate Venturing in the Diversified Major Firm. Administrative Science Quarterly, 28(2), pp. 223-244.

Chandler, A.D. (1962). Strategy and Structure: Chapters in the History of the Industrial Enterprise. Cambridge, MA: MIT Press.

Chang, C.C. (2006). When Service Fails: The Role of the Salesperson and the Customer. Psychology and Marketing, 23(3), pp. 203-224.

Charles, K. and Dawson, P. (2011). Dispersed Change Agency and the Improvisation of Strategies during Processes of Change. Journal of Change Management, 11(3), pp. 329-351.

Chelariu, C., Johnston, W.J., and Young, L. (2002). Learning to Improvise, Improvising to Learn: A Process of Responding to Complex Environments. Journal of Business Research, 55, pp. 141-147.

Ciborra, C.U. (1996). The Platform Organization: Recombining Strategies, Structures, and Surprises. Organization Science, 7(2), pp. 103-118.

Ciborra, C.U. (1999) Notes on Improvisation and Time in Organizations. Accounting, Management \& Information Technologies, 9, pp. 77-94.

Cleary, M.J. and Groer, S. (1994). Inflight Decisions of Expert and Novice Health Teachers. Journal of School Health, 84, pp. 110-114.

Crossan, M.M. (1997). Improvise to Innovate. Ivey Business Quarterly, 62(1), pp. 37-42. 
Crossan, M.M. (1998). Improvisation in Action. Organization Science, 9(5), pp. 593-599.

Crossan, M.M., Cunha, M.P, Vera, D. and Cunha, J. (2005). Time and Organizational Improvisation. Academy of Management Review, 30(1), pp. 129-145.

Crossan, M.M., Lane, H., White, R.E. and Klus, L. (1996). The Improvising Organization: Where Planning Meets Opportunity. Organizational Dynamics, 24(4), pp. 20-35.

Crossan, M.M. and Sorrenti, M. (1997). Making Sense of Improvisation. Advances in Strategic Management, 14, pp. 155-180.

Crossan, M.M. and Sorrenti, M. (2002). Making Sense of Improvisation. In Kamoche, K.; Cunha, M.P. and Cunha, J.V. (eds.). Organizational Improvisation. London, UK: Routledge, pp. 27-48.

Csikszentmihalyi, M. (1990). Flow: The Psychology of Optimal Experience. New York: Harper and Row.

Cunha, M.P., Cunha, J.V. and Kamoche, K. (1999). Organizational Improvisation: What, When, How and Why. International Journal of Management Reviews, 1(3), pp. 299341.

Cunha, M.P., Kamoche, K. and Cunha, R.C. (2003). Organizational Improvisation and Leadership: A Field Study in Two Computer-mediated Settings. International Studies of Management \& Organization, 33(1), pp. 34-57.

Cunha, M.P., Rego, A. and Kamoche, K. (2009). Improvisation in Service Recovery. Managing Service Quality, 19(6), pp. 657-669.

Damanpour, F. (1991). Organizational Innovation: A Meta-analysis of Effects of Determinants and Moderators. Academy of Management Journal, 34(3), pp. 555-590.

D'Aveni, R.A. (1994). Hypercompetition: Managing the Dynamics of Strategic Maneuvering. New York: Free Press.

De Meyer, A., Nakane, J., Miller, J.G. and Ferdows, K. (1989). Flexibility: The Next Competitive Battle. Strategic Management Journal, 10(2), pp. 135-144.

Dennis, N. and Macaulay, M. (2007). 'Miles Ahead' - Using Jazz to Investigate Improvisation and Market Orientation. European Journal of Marketing, 41(5/6), pp. 608-623.

De Tienne, D. and Mallette, P. (2012). Antecedents and Outcomes of Innovation-Oriented Cultures. International Journal of Business and Management, 7(18), pp. 1-11.

Dewett, T. and Williams, S. (2007). Innovators and Imitators in Novelty-Intensive Markets: A Research Agenda. Creativity \& Innovation Management, 16(10), pp. 80-92. 
Drabek, T. and McEntire, D. (2002). Emergent Phenomena and Multiorganizational Coordination in Disasters: Lessons from the Research Literature. International Journal of Mass Emergencies and Disasters, 20(2), pp. 197-224.

Dutton, J.E. (2003). Energize Your Workplace: How to Create and Sustain High-Quality Connections at Work. San Francisco: Jossey-Bass.

Eisenberg, E. (1990). Jamming! Transcendence Through Organizing. Communication Research, 17(2), pp. 139-164.

Eisenhardt, K.M. (1989). Making Fast Strategic Decisions in High-velocity Environments. Academy of Management Journal, 32(3), pp. 543-576.

Eisenhardt, K.M. and Tabrizi, B.N. (1995). Accelerating Adaptive Processes: Product Innovation in the Global Computing Industry. Administrative Science Quarterly, 40(1), pp. 84-110.

Eisenhardt, K.M., Kahwajy, J.L. and Bourgeois, L.J. (1997). Conflict and Strategic Choice. California Management Review, 39(2), pp. 42-62.

Evers, N. and O'Gorman, C. (2011). Improvised Internationalization in New Ventures: The Role of Prior Knowledge and Networks. Entrepreneurship \& Regional Development, 23(7/8), pp. 549-574.

Ferriani, S., Garnsey, E. and Lorenzoni, G. (2011). Continuity and Change in a Spin-off Venture: The Process of Reimprinting. Industrial \& Corporate Change, 21(4), pp. 1011-1048.

Frost, P.J. (1998). Unsung Heroes: An Interview with Steve Havlovic. Organization Science, 9(5), pp. 577-582.

Gagnon, S., Vough, H.C. and Nickerson, R. (2012). Learning to Lead, Unscripted: Developing Affiliative Leadership through Improvisational Theatre. Human Resource Development Review, 11(3), pp. 299-325.

Gardner, W. and Rogoff, B. (1990). Children's Deliberateness of Planning According to Task Circumstances. Developmental Psychology, 26(3), pp. 480-487.

Gibb, S. (2004). Arts-based Training in Management Development: The Use of Improvisational Theatre. Journal of Management Development, 23(8), pp. 741-750.

Gilson, C., Roberts, K., Weymes, E. and Pratt, M. (2001). Peak Performance: Business Lessons from the World's Top Sports Organizations. London, UK: Harper Collins Business. 
Grayson, D., McLaren, M. and Spitzeck, H. (2014). Social Intrapreneurism and All That Jazz: How Business Innovators are Helping to Build a More Sustainable World. Sheffield, UK: Greenleaf Publishing.

Grove, A.S. (1996). Only the Paranoid Survive. New York: Doubleday Business.

Hadida, A.L. (2013). Let Your Hands Do the Thinking! Lego Bricks, Strategic Thinking and Ideas Generation within Organizations. Strategic Direction, 29(2), pp. 3-5.

Hamel, G. and Breen, B. (2007). The Future of Management. Boston, MA: Harvard Business School Press.

Hatch, M.J. (1997). Jazzing Up the Theory of Organizational Improvisation. Advances in Strategic Management, 14(2), pp. 181-191.

Hatch, M.J. (1998). Jazz as a Metaphor for Organizing in the $21^{\text {st }}$ Century. Organization Science, 9(5), pp. 565-568.

Hatch, M.J. (1999). Exploring the Empty Spaces of Organizing: How Improvisional Jazz helps Redescribe Organizational Structure. Organization Studies, 20(1), pp. 75-100.

Hatch, M.J. and Weick, K.E. (1998). Critical Resistance to the Jazz Metaphor. Organization Science, 9(5), pp. 600-604.

Hmieleski, K.M. and Corbett, A.C. (2008). The Contrasting Interaction Effects of Improvisational Behavior with Entrepreneurial Self-efficacy on New Venture Performance and Entrepreneur Work Satisfaction. Journal of Business Venturing, 23, pp. 482-496.

Holbrook, M.B. (2007). Playing the Changes on the Jazz Metaphor: An Expanded Conceptualization of Music-, Management-, and Marketing-related Themes. Foundations and Trends in Marketing, 2(3/4), pp. 185-442.

Horowitz, B. (2014). The Hard Thing about Hard Things: Building a Business When There are No Easy Answers. New York: Harper Business.

Hudak, P. and Berger, J. (1995). A Model of Performance, Interaction, and Improvisation. In International Computer Music Conference Proceedings. San Francisco, CA: The International Computer Music Association, pp. 541-548.

Hutchins, E. (1991). Organizing Work by Adaptation. Organization Science, 2(1), pp. 14-39. Isaacson, W. (2011). Steve Jobs. New York: Simon \& Schuster.

Jackson, S. and Philip, G. (2010). A Techno-cultural Emergence Perspective on the Management of Techno-change. International Journal of Information Management, 30(5), pp. 445-456. 
Jaikumar, R. (1986). Postindustrial Manufacturing. Harvard Business Review, 64(6), pp. 6977.

Janos, L. and Rich, B.R. (1994). Skunk-Works: A Personal Memoir of My Years at Lockheed. New York: Little, Brown and Company.

John, J., Grove, S.J. and Fisk, R.P. (2006). Improvisation in Service Performances: Lessons from Jazz. Managing Service Quality, 16(3), pp. 247-268.

Kamoche, K. and Cunha, M.P. (1997). Teamwork, Knowledge-creation and Improvisation. In Proceedings from the International Workshop on Teamworking. Nottingham, UK: University of Nottingham, pp. 358-374.

Kamoche, K. and Cunha, M.P. (2001). Minimal Structures: From Jazz Improvisation to Product Innovation. Organization Studies, 22(5), pp. 733-764.

Kamoche, K., Cunha, M.P. and Cunha, J.V. (2000). Shopping for New Glasses: Looking Beyond Jazz in the Study of Organizational Improvisation. Working paper, 381, Lisbon, Portugal: New University of Lisbon.

Kamoche, K., Cunha, M.P. and Cunha, R.C. (2003). Towards a Theory of Organizational Improvisation: Looking Beyond the Jazz Metaphor. Journal of Management Studies, 40(8), pp. 2023-2051.

Kao, J. (1996a). Jamming: The Art and Discipline of Business Creativity. New York: HarperCollins.

Kao, J. (1996b). The Heart of Creativity. Across the Board, 33(8), pp. 23-27.

Kernfeld, B. (1995). What to Listen For in Jazz. New Haven, CT: Yale University Press.

King, A.W. and Ranft, A.L. (2001). Capturing Knowledge and Knowing Through Improvisation: What Managers Can Learn from the Thoracic Surgery Board Certification Process. Journal of Management, 27(3), pp. 255-277.

Kirsch, L.J. (1996). The Management of Complex Tasks in Organizations: Controlling the Systems Development Process. Organization Science, 7(1), pp. 1-21.

Koppett, K. (2002). Business and the Art of Improvisation. British Journal of Administrative Management, 33, pp. 26-28.

Kyriakopoulos, K. (2011). Improvisation in Product Innovation: The Contingent Role of Market Information Sources and Memory Types. Organization Studies, 32(8), pp. 1051-1078.

Larson, M. (2011). Innovation and Creativity in Festival Organizations. Journal of Hospitality Marketing \& Management, 20(3/4), pp. 287-310. 
Leonard-Barton, D. and Leonard, D. (1995). Wellsprings of Knowledge: Building and Sustaining the Sources of Innovation. Boston, MA: Harvard Business School Publishing.

Lewin, A.Y. (1998). Jazz Improvisation as a Metaphor for Organization Theory. Organization Science, 9(5), p. 539.

Leybourne, S. (2006). Managing Change by Abandoning Planning and Embracing Improvisation. Journal of General Management, 31(3), pp. 11-29.

Leybourne, S. (2010a). Project Management and High-Value Superyacht Projects: An Improvisational and Temporal Perspective. Project Management Journal, 41(1), pp. $17-27$.

Leybourne, S. (2010b). Improvisation as a Way of Dealing with Ambiguity and Complexity. Graziadio Business Report, 13(3).

Leybourne, S. and Sadler-Smith, E. (2006). The Role of Intuition and Improvisation in Project Management. International Journal of Project Management, 24, pp. 483-492.

Lockford, L. and Pelias, R.J. (2004). Bodily Poeticizing in Theatrical Improvisation: A Typology of Performative Knowledge. Theatre Topics, 14, pp. 431-443.

Machin, D. and Carrithers, M. (1996). From Interpretative Communities to Communities of Improvisation. Media, Culture \& Society, 18, pp. 343-352.

MacKenzie, K.D. (1986). Virtual Positions and Power. Management Science, 32, pp. 622642.

Magni, M., Proserpio, L., Hoegl, M., and Provera, B. (2009). The Role of Team Behavioral Integration and Cohesion in Shaping Individual Improvisation. Research Policy, 38, pp. 1044-1053.

Magni, M., Provera, B. and Proserpio, L. (2008). Improvisation in Geographically-dispersed Teams: Does Distance Matter? In IX Workshop dei Docenti e dei Ricercatori di Organizzazione Aziendale, Venice, Italy: Università Ca' Foscari.

Magni, M., Provera, B. and Proserpio, L. (2010). Individual Attitude toward Improvisation in Information Systems Development. Behavior \& Information Technology, 29(3), pp. 245-255.

Mantere, S., Sillince, J.A.A. and Hämäläinen, V. (2007). Music as a Metaphor for Organizational Change. Journal of Organizational Change Management, 20(3), pp. 447-459.

March, J.G. (1991). Exploration and Exploitation in Organizational Learning. Organization Science, 2(1), pp. 71-87. 
March, J.G. and Simon, H.A. (1958). Organizations. New York: Wiley.

Marotto, M., Roos, J. and Victor, B. (2007). Collective Virtuosity in Organizations: A Study of Peak Performance in an Orchestra. Journal of Management Studies, 44(3), pp. 388413.

McCourt, W. (1997). Using Metaphors to Understand and to Change Organizations: A Critique of Gareth Morgan's Approach. Organization Studies, 18(3), pp. 511-522.

McKnight, B. and Bontis, N. (2002). E-improvisation: Collaborative Groupware Technology Expands the Reach and Effectiveness of Organizational Improvisation. Knowledge and Process Management, 9(4), pp. 219-227.

Mendonca, D. and Wallace, W. (2004). Studying Organizationally-Situated Improvisation in Response to Extreme Events. International Journal of Mass Emergencies and Disasters, 22(2), pp. 5-29.

Meyer, A. (1998). Organizing for Improvisation: The Backstage Story of the Vancouver Jazz Concert. Organization Science, 9(5), pp. 569-576.

Meyer, P. (2005). Organizational Improvisation and Appreciative Inquiry: An Exploration of Symbiotic Theory and Practice. In Midwest Academy of Management $48^{\text {th }}$ Annual Meeting (Louisville, KY), pp. 1-18.

Meyer, A., Frost, P.J. and Weick, K.E. (1998). The Organization Science Jazz Festival: Improvisation as a Metaphor for Organising. Organization Science, 9(5), pp. 540-542.

Meyer, G.W. and Shambu, G. (2010). The Jazz Metaphor for Management Educators: Making Meaning with Students through Swinging Improvisation. Business Education Innovation Journal, 2(1), pp. 16-26.Miner, A., Bassoff, P. and Moorman, C. (2001). Organizational Improvisation and Learning: A Field Study. Administrative Science Quarterly, 46(2), pp. 304-337.

Miner, A., Moorman, C. and Bassoff, P. (1997). Organizational Improvisation in New Product Development. In MSI Report, 97-110, Cambridge, MA: Marketing Science Institute.

Mintzberg, H. (1990). The Design School: Reconsidering the Basic Premises of Strategic Management. Strategic Management Journal, 11(3), pp. 171-195.

Mintzberg, H. (1991). Learning 1, Planning 0: Reply to Igor Ansoff. Strategic Management Journal, 12(6), pp. 463-466.

Mintzberg, H. (1994). The Fall and Rise of Strategic Planning. Harvard Business Review, 72(1), pp. 107-114. 
Mintzberg, H. and McHugh, A. (1985). Strategy Formation in an Adhocracy. Administrative Science Quarterly, 30(2), pp. 160-197.

Mintzberg, H. and Waters, J.A. (1985). Of Strategies, Deliberate and Emergent. Strategic Management Journal, 6(3), pp. 257-272.

Mirvis, P.H. (1998). Practice Improvisation. Organization Science, 9(5), pp. 586-592.

Moorman, C. and Miner, A. (1995). Walking the Tightrope: Improvisation and Information in New Product Development. MSI Report, 95-101, Cambridge, MA: Marketing Science Institute.

Moorman, C. and Miner, A. (1998a). The Convergence between Planning and Execution: Improvisation in New Product Development. Journal of Marketing, 62, pp. 1-20.

Moorman, C. and Miner, A. (1998b). Organizational Improvisation and Organizational Memory. Academy of Management Review, 23(4), pp. 698-723.

Morgan, G. (1980). Paradigms, Metaphors and Puzzle Solving in Organizational Theory. Administrative Science Quarterly, 25(4), pp. 605-622.

Morgan, G. (1998). Images of Organization: The Executive Edition. Thousand Oaks, CA: SAGE Publications.

Moss Kanter, R. (2002) .Strategy as Improvisational Theatre. Sloan Management Review. Winter, pp. 76-81.

Newell, A. and Simon, H. (1972). Human Problem Solving. Englewood Cliffs, NJ: PrenticeHall.

Newton, P.M. (2004). Leadership Lessons from Jazz Improvisation. International Journal of Leadership in Education, 7(1), pp. 83-99.

Nonaka, I. and Konno, N. (1998). The Concept of Ba: Building a Foundation for Knowledge Creation. California Management Review, 40(3), pp. 40-54.

Nonaka, I. and Takeuchi, H. (1995). The Knowledge-creating Company. New York: Oxford University Press US.

Nunez, E. and Lynn, G.S. (2012). The Impact of Adding Improvisation to Sequential NPD Processes on Cost: The Moderating Effects of Turbulence. Academy of Marketing Studies Journal, 16(1), pp. 1-18.

Olson, E., Walker, O.C. and Ruekert, R. (1995). Organizing for Effective New Product Development: The Moderating Role of Product Innovativeness. Journal of Marketing, 59, pp. 48-62.

Orlikowski, W.J. (1996). Improvising Organizational Transformation over Time: A Situated Change Perspective. Information Systems Research, 7(1), pp. 63-92. 
Orlikowski, W.J. and Hofman, J.D. (1997). An Improvisational Model for Change Management: The Case of Groupware Technologies. Sloan Management Review, 38(2), pp. 11-21.

Oxford Dictionaries (2014). improvise. Oxford University Press. Retrieved 23 February 2014, from: http://oxforddictionaries.com/definition/improvise.

Pascale, R.T. (1984). Perspectives on Strategy: The Real Story Behind Honda's Success. California Management Review, 25(3), pp. 47-72.

Pasmore, W.A. (1998). Organizing for Jazz. Organization Science, 9(5), pp. 562-564.

Pavlou, P.A. and El Sawy, O.A. (2010). The "Third Hand": IT-Enabled Competitive Advantage in Turbulence Through Improvisational Capabilities. Information Systems Research, 21(3), pp. 443-471.

Pavlovich, K. (2003). All That Jazz. Long Range Planning, 36(5), pp. 441-458.

Peplowski, K. (1998). The Process of Improvising. Organization Science, 9(5), pp. 560-561.

Perry, L.T. (1991). Strategic Improvising: How to Formulate and Implement Competitive Strategies in Concert. Organizational Dynamics, 19(4), pp. 51-64.

Peters, T. and Waterman, R. (1982). In Search of Excellence. New York: Harper \& Row.

Plowman, D.A., Baker, L.T., Beck, T.E., Kulkarni, M., Solansky, S.T. and Travis, D.V. (2007). Radical Change Accidentally: The Emergence and Amplification of Small Change. Academy of Management Journal, 50, pp. 515-543.

Powers, C. (1981). Role Imposition or Role Improvisation: Some Theoretical Principles. The Economic \& Social Review, 12(4), pp. 287-299.

Prashantham, S. and Floyd, S.W. (2012). Routine Microprocesses and Capability Learning in International New Ventures. Journal of International Business Studies, 43, pp. 544562.

Preston, A. (1991). Improvising Order. In Mangham, I.L. (ed.). Organization Analysis and Development. New York: Wiley, pp. 81-102.

Ramalho, G. and Ganascia, J. (1994). Simulating Creativity in Jazz Performance. Proceedings of the $20^{\text {th }}$ National Conference on Artificial Intelligence. Seattle, WA: AAAI Press, pp. 108-113.

Ramos, R. (1978). The Use of Improvisation and Modulation in Natural Talk: An Alternative Approach to Conversational Analysis. Studies in Symbolic Interaction, 1(1), pp. 319337.

Ranson, S., Hinings, B., and Greenwood, R.T. (1980). The Structuring of Organizational Structures. Administrative Science Quarterly, 25(1), pp. 1-17. 
Rerup, C. (2001). 'Houston, We Have a Problem': Anticipation and Improvisation as Sources of Organizational Resilience. Comportamento Organizacional e Gestão, 7(1), pp. 2144.

Rosner, M. M. (1968). Economic Determinants of Organizational Innovation. Administrative Science Quarterly, 12(4), pp. 614-625.

Samra, Y.M., Lynn, G.S. and Reilly, R.R. (2008). Effect of Improvisation on Product Cycle Time and Product Success: A Study of New Product Development (NPD) Teams in the United States. International Journal of Management, 25(1), pp. 175-185.

Sawyer, K. (1992). Improvisational Creativity: An Analysis of Jazz Performance. Creativity Research Journal, 5(3), pp. 253-263.

Schloss, A. and Jaffe, D.A. (1993). Intelligent Musical Instruments: The Future of Musical Performance or the Demise of the Performer? Journal of New Music Research, 22(3), pp. 183-193.

Schön, D.A. (1987). Educating the Reflective Practitioner. San Francisco, CA: Jossey-Bass.

Schreyögg, G. and Sydow, J. (2010). Organizing for Fluidity? Dilemmas of New Organizational Forms. Organization Science, 21(6), pp. 1251-1262.

Schuller, G. (1968). Early Jazz. New York: Oxford University Press US.

Seelig, T. (2012). InGenius: A Crash Course on Creativity. London, UK: Hay House UK Ltd.

Senge, P.M. (1990). The Fifth Discipline: The Art and Practice of the Learning Organization. London, UK: Century Business.

Sharron, A. (1983). Time and Space Bias in Group Solidarity: Action and Process in Musical Improvisation. International Social Science Review, 58(4), pp. 222-230.

Silva, L. (2002). Outsourcing as an Improvisation: A Case Study in Latin America. The Information Society, 18(2), pp. 129-138.

Singh, S. and Sonnenburg, S. (2012). Brand Performances in Social Media. Journal of Interactive Marketing, 26(4), pp. 189-197.

Sonenshein, S. (forthcoming). How Organizations Foster the Creative Use of Resources. Academy of Management Journal.

Song, M., Im, S., van der Bij, H. and Song, L.Z. (2011). Does Strategic Planning Enhance or Impede Innovation and Firm Performance? Journal of Product Innovation Management, 28(4), pp. 503-520. 
Soules, M. (2002). Improvising Character: Jazz, the Actor, and Protocols in Improvisation. In Heble, A. and Fischlin, D. (eds.). The Other Side of Nowhere: Jazz, Improvisation and Cultural Theory. Middletown, CT: Wesleyan University Press, pp. 268-297.

Starbuck, W.H. and Farjoun, M. (2005). Organization at the Limit: Lessons from the Columbia Disaster. Malden, MA: Blackwell Publishing.

Steinbock, D. (2010). Winning Across Global Markets: How Nokia Creates Strategic Advantage in a Fast-changing World. San Francisco, CA: Jossey-Bass.

Sutton, R.I. and Hargadon, A. (1996). Brainstorming Groups in Context: Effectiveness in a Product Design Firm. Administrative Science Quarterly, 41(4), pp. 685-718.

Tanenbaum, J. and Tanenbaum, K. (2008). Improvisation and Performance as Models for Interacting with Stories. Interactive Storytelling: Lecture Notes in Computer Science. 5334, pp. 250-263.

Taylor, F.W. (1911). The Principles of Scientific Management. New York: Harper Bros.

Tsoukas, H. (1991). The Missing Link: A Transformational View of Metaphors in Organizational Science. Academy of Management Review, 16(3), pp. 566-585.

Tsoukas, H. (1993). Analogical Reasoning and Knowledge Generation in Organizational Theory. Organization Studies, 14(3), pp. 323-346.

Vendelø, M.T. (2009). Improvisation and Learning in Organizations - An Opportunity for Future Empirical Research. Management Learning, 40(4), pp. 449-456.

Vera, D. and Crossan, M.M. (1999). Improvisation: A Theoretical Model of its Dimensions, Antecedents, Outcomes, and Moderating Variables. Working paper, 1999-10. London, ON, Canada: Richard Ivey School of Business.

Vera, D. and Crossan, M. (2004). Theatrical Improvisation: Lessons for Organizations. Organization Studies, 25(5), pp. 727-749.

Vera, D. and Crossan, M.M. (2005). Improvisation and Innovative Performance in Teams. Organization Science, 16(3), pp. 203-224.

Vera, D. and Rodriguez-Lopez, A. (2007). Leading Improvisation: Lessons from the American Revolution. Organizational Dynamics, 36(3), pp. 303-319.

Vitug, M. and Kleiner, B. (2007). How Can Comedy Be Used in Business? International Journal of Productivity \& Performance Management, 56(2), pp. 155161.

Vuori, N. and Vuori, T. (2014). Heuristics in the Strategy Context - Commentary on Bingham and Eisenhardt (2011). Strategic Management Journal, in press. 
Webb, G. and Chevreau, F.R. (2006). Planning to Improvise: The Importance of Creativity and Flexibility in Crisis Response. International Journal of Emergency Management, 3(1), pp. 8-9.

Weick, K.E. (1993a). Organizational Redesign as Improvisation. In Huber, G.P. and Glick, W.H. (eds.). Organizational Change and Redesign. New York: Oxford University Press US, pp. 346-379.

Weick, K.E. (1993b). The Collapse of Sensemaking in Organizations: The Mann Gulch Disaster. Administrative Science Quarterly, 38(4), pp. 628-652.

Weick, K.E. (1996). Drop Your Tools: An Allegory for Organizational Studies. Administrative Science Quarterly, 41(2), pp. 301-313.

Weick, K.E. (1998). Improvisation as a Mindset for Organizational Analysis. Organization Science, 9(5), pp. 543-555.

Weick, K.E. (2001). Making Sense of the Organization. Oxford, UK: Blackwell.

Werner, K. (1996). Effortless Mastery: Liberating the Master Musician Within. New Albany, IN: Jamey Aebersold Jazz.

Wheeler, M. and Morris, G. (2002). A Note on Maneuvering in War and Negotiation. Cambridge, MA: President and Fellows of Harvard College, Harvard Business School Publishing.

Woodman, R.W., Sawyer, J.E. and Griffin, R.W. (1993). Toward a Theory of Organizational Creativity. Academy of Management Review, 18(2), pp. 293-321.

Yanow, D. and Tsoukas, H. (2009). What is Reflection-in-action? A Phenomenological Account. Journal of Management Studies, 46(8), pp. 1339-1364.

Zack, M. (2000). Jazz Improvisation and Organizing: Once More from the Top. Organization Science, 11(2), pp. 227-234.

Zander, R.S. and Zander, B. (2000). The Art of Possibility: Transforming Professional and Personal Life. Cambridge, MA: Harvard Business School Press.

Zheng, Y., Venters, W. and Cornford, T. (2011). Collective Agility, Paradox and Organizational Improvisation: The Development of a Particle Physics Grid. Information Systems Journal, 21, pp. 303-333. 


\footnotetext{
${ }^{1}$ Heuristics are defined as cognitive shortcuts that emerge when information, time, and processing capacity are limited (Newell and Simon 1972). By providing common structures for a range of similar problems (Bingham and Eisenhardt 2011), they "enable individuals to simplify cognitive processing, conserve attention, and decide more quickly" while also "leaving room to improvise in real time" and allowing "flexibility to improvise for unique features of particular opportunities" (Bingham and Eisenhardt 2014: in press).

${ }^{2}$ We wish to thank one anonymous reviewer for pointing out the challenges and irony of developing a consolidating model of organizational improvisation, and for suggesting ways to address these concerns.

${ }^{3}$ The authors of the two studies changed the names of these two organizations to ensure informants' anonymity. ${ }^{4}$ For the sake of clarity and completeness, please note that Kamoche and Cunha (2001) define "constrained improvisation" as "minimal structures". We opted for the former terminology, however, to avoid confusion with "minimal structuring", which occurs at the interpersonal rather than organizational level.
} 